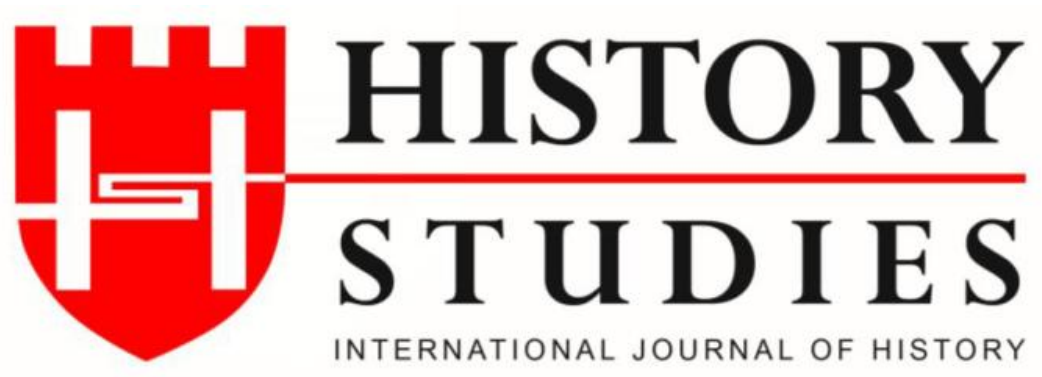

\author{
ISSN: 13094173 (Online) 1309 - 4688 (Print) \\ Volume 12 Issue 4, August 2020 \\ DOI Number: 10.9737/hist.2020.920 \\ Araştırma Makalesi \\ Makalenin Geliş Tarihi: 02.07.2020 Kabul Tarihi: 28.07.2020 \\ Atıf Künyesi: Ahmet Yüksel, "Sami Hochberg A Zionist Journalist Author Printer Diplomat Spy", \\ History Studies, 12/4, Ağustos 2020, s. 2263-2297.
}

\title{
Sami Hochberg A Zionist Journalist Author Printer Diplomat Spy
}

Sami Hochberg: Bir Siyonist, Gazeteci, Yazar, Matbaacl, Diplomat, Casus

\author{
Assoc. Prof. Dr. Ahmet Yüksel \\ ORCID No: 0000-0001-5353-1989 \\ Sivas Cumhuriyet University
}

\begin{abstract}
Sami Hochberg is a relatively famous Zionist in the Western world, especially among Jews. It is not a common occurrence to coincide with him in the literature related to Ottoman history, even though he had spent the most active days of his life in Istanbul. However, the events that he was involved in are of their own importance in terms of their shape and years of occurrence. The city and countries where Sami Hochberg lived, and his relatively richer and more colorful life in terms of his attributes and identities present us not only how the Ittihat and Terakki government followed a policy against Zionists, Arabs and the European Great Powers before and during the First World War but also what lies in the historical background of the reconciliation or conflict of that groups in question. However, the current literature on him sometimes presents interruptions and gaps in presenting these sections to the reader, and sometimes in combining the sections to reveal the big picture. The documents related to Sami Hochberg encountered in the Ottoman archives have awaked such a conviction on the researcher. One of the main objectives of this study is to be able to bring together Samuel Hochberg (in the literatüre) and Sami Hoşberg (in documents) as a step towards the removal of the mentioned gaps. Thus from Sami Hochberg's point of view it will be possible to consider some developments like rivalry, conflict and partial reconciliation among the religious, ethnic and the political forces some of which are listed above and many of which will be referred in the course of the study.
\end{abstract}

Keywords: Sami Hochberg, Zionism, Union and Progress, Espionage, Print Press.

Öz: Sami Hochberg, Batı dünyasında ve bilhassa Museviler arasında nispeten şöhret sahibi bir Siyonist'tir. Hayatının en hareketli günlerini İstanbul'da geçirmiş olmasına rağmen Osmanlı tarih literatüründe kendisine tesadüf etmek çok sıklıkla karşılaşılan bir hadise değildir. Oysa onun, ekseninde yer aldığı olaylar meydana geliş şekil ve yılları itibariyle kendince bir önem atfeder. Mesela Sami Hochberg'in yaşadığı şehir ve ülkelerle, sahip olduğu sıfat ve kimlikler itibariyle görece bir zenginlik ve renklilik aksettiren yaşantısı, I. Dünya Savaşı'nın öncesinde ve içerisinde hem İttihat ve Terakki hükümetlerinin Siyonistler, Araplar ve Avrupalı Büyük Güçlere karşı nasıl bir politika takip ettiklerine hem de söz konusu grupların birbirleriyle olan uzlaşı yahut çatışmalarının tarihî arka 
planında nelerin yattığını görebilmeye dair kesitler sunar. Ancak onunla ilgili mevcut literatür bazen o kesitleri okuyucusuna sunma bazen de o kesitleri birleştirip büyük resmi ortaya çıkarabilme noktasında kesinti ve boşluklar arz eder. Osmanlı arşivinde rast gelinen Sami Hochberg temalı vesikalar araştırmacıda böyle bir kanaat uyandırmıştır. Vesikalardaki Sami Hoşberg ile literatürdeki Samuel Hochberg’i buluşturup, bahsedilen boşlukların giderilmesine hizmet edebilmek yolunda bir adım atmış olmak, bu çalışmanın kaleme alınmasının temel gayelerindendir. $\mathrm{Bu}$ sayede yukarıda bazıları sıralanan ve çalışma içerisinde daha nicelerine temas edilecek olan siyasî güçlerle, dinî ve etnik gruplar arasındaki rekabet, çatışma ve kısmen de uzlaşma gibi gelişmelere Sami Hochberg'in dünyasından bakabilmek mümkün olacaktır.

Anahtar Kelimeler: Sami Hochberg, Siyonizm, İttihad ve Terakki, Casusluk, Matbaa.

\section{Methodical and Biographical Introduction}

Smelling the political atmosphere of the period to which, the subject matter of the study belongs and presenting a general portrait of the relevant historical figures are the sine qua non for the introduction part of each research. In this way, it can be possible to eliminate the deficiencies related to the study and to make accurate evaluations and inferences and, more importantly, to ensure an uninterrupted narration of the subject. Similarly, the possibility of contributing to the political atmosphere or field mentioned in and as a result of the study will also arise. However, the author was encountered with Sami in a platform where he keeps an eye on the cultural and political history that combined in almost every subject, place and time. Since the intense issues such as military, politics and cultural in the world and around him are so diverse that they cannot be brought together in the introduction part of a study so those topics will be touched as they come in the text. In other words, the narration of events that occurred in the days when the smell of gunpowder mingles with the printing press ink for the first time in the world is left to the natural and chronological flow of Hochberg's life.

The literature on the biography of Sami Hochberg offers a wealth that may be deemed sufficient. Where that literature is inadequate, Ottoman documents give the impression that they are ready to step in. However, the information contained in the documents sometimes experiences some minor conflicts with the literature. The first of them is about on Sami Bey's surname. In fact, the documents are in conflict with not only the literature but also in themselves: Hofberg ${ }^{1}$, Hohberg $^{2}$, Homberg $^{3}$ and Hoşberg ${ }^{4} \ldots$ This is caused by the fact that Ottoman clerks recorded foreign names in the way they were pronounced or what they heard. In fact, a similar situation applies to the first name. Because Sami Bey's Hebrew name is Shmuel (Samuel and sometimes Sam - Sammy).

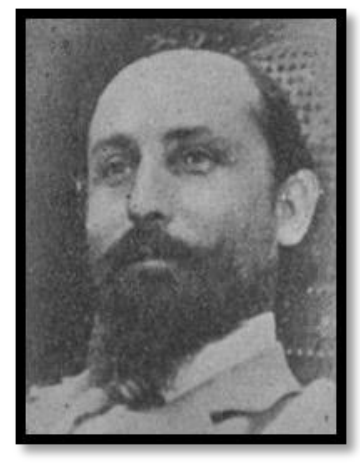

Sami Hochberg's photograph. Source: Encyclopedia of the Founders and Builders of Israel, Vol. 1, p. 416; http://www.tidhar.tourol

${ }^{1}$ BOA, DH.EUM. 5. Şb., 32/33; p.9; 12 Kanunuevvel 1332/25 December 1916. See. Annex 4.

${ }^{2}$ BOA, DH.EUM. 5. Şb., 81/12; p.1, 9, 11; 23 Nisan 1331/6 May 1915. See. Annex 3; BOA, DH.EUM. 5. Şb., 32/33; p.23; 11 Teşrinievvel 1332/24 October 1916.

BOA, DH.EUM. 5. Şb., 32/33; p.41; 5 Teşrinievvel 1332/18 October 1916; BOA, HR.SYS. 2267/37; 31 August 1916. See. Annex 1.

${ }^{4}$ BOA, DH.EUM. 5. Şb., 32/33; p.45; 1 Ağustos 1332/14 August 1916; BOA, DH.EUM. 5. Şb., 22/28; p.1, 3; 8 Mart 1332/21 March 1916; BOA, DH.EUM. 5. Şb., 81/12; p.4; 13 May 1332/26 May 1916; BOA, HR.SYS., 2267/19; p.2; 3 May 1332/16 May 1916, see. Annex 5; BOA, HR.SYS. 2267/23; 25 June 1916; BOA, HR.SYS. 2267/37; 31 August 1916; BOA, HR.SYS. 2267/41; 10 September 1916. 
Sami Hochberg's year of birth was 1869 . The place of birth was Dumbraveni in the territory of Bessarabia, which was located at that times within the borders of Russia (today Romania). In Ottoman documents, there are generally estimated numbers about his age. It was recorded in a document of 1915 that he could be at the age of $35-40^{5}$, whereas in two different documents of the next year, it was noted that he could be 45 years old. ${ }^{6}$ The same year, Sami Hochberg, himself put an end to the discussion about his age among the documents: 'I am 47 years old by $1916^{\prime}$.

Sami Hochberg's father was Mordechai who was engaged in farming. ${ }^{8}$ In his youth, Sami Bey studied trade in Odessa that belonged to Russia (now in Ukraine) at that time as a port city where $660 \mathrm{~km}$ far from his birth place. ${ }^{9}$ When the Jewish Holocaust began in Russia at 1881, at the same time he introduced with the Zion Lovers (Hovevei Zion) during his University years ${ }^{10}$ whose included young Slavic Jews. $\mathrm{He}^{11}$ also migrated to Jaffa by sea in 1889 , when he was only 20 years old; was presumed to be followed the Rothschilds who organized and supported the colonization of the Jewish families in Palestine... ${ }^{12}$

\section{Hochberg the Emigrant}

N. J. Mandel, in his comprehensive article on Jewish immigration and Arab-Jewish relations in Palestine, noted that those who had come to Palestine since the 1880s, such as Sami Hochberg, had been living in many rural settlements outside the four sacred Jewish cities especially Haifa and Jaffa. The Jews initially accounted for twelve per cent of the population in Palestine with 50,000 people, and since the 1910s onwards the demographic data increased almost to 100,000. At the same time, the Lovers of Zion, with over 30,000 members, accounted for one-third of the total Jewish population. Almost half of the lovers of Zion were in the cities,

Volume 12

${ }^{5}$ BOA, DH.EUM. 5. Şb., 81/12; p.4; 13 May 1332/26 May 1916.

6. BOA, DH.EUM. 5. Şb., 32/33; p.57, 59; 7 Nisan 1332/20 April 1916.

${ }^{7}$ BOA, DH.EUM. 5. Şb., 32/33; p.25; 14 September 1916.

${ }^{8}$ His father's name was recorded as Mordohay in documents. See. BOA, DH.EUM. 5. Şb., 81/12; p.9; His mother's name was Esther Reiza; his grandfather was a famous writer R. Zvi Hirsch and one of the school teachers of his was Yechiel Greenfeld who translated A. Einstein's theory into Hebrew. See. Encyclopedia of the Founders and Builders of Israel, Vol. 1, p. 416; http://www.tidhar.tourolib.org/tidhar/view/1/416 (access date: 29 May 2020).

${ }^{9}$ Shany Littman is the only source that enables us to make assumptions that Hochberg studied business in Odessa. See. Shany Littman, "Saved From History's Black Hole", Haaretz, 12.11.2010, Access date: 19.12.2018., https://www.haaretz.com/1.5138700; It would be more proper to emphasize that Hochberg is rather studying on the "trade" of that age instead of "business department" of the modern world. There were three well-established universities at that date in the region (today Ukraine), University of Kharkov (1804), Kyiv [Kiev] University (1834) and Odessa University (1864). We also know that he studied at a regional school in Soroca where approximately $400 \mathrm{~km}$ far from Dumbraveni. See. Encyclopedia of the Founders ..., p. 416.

${ }^{10}$ The word Zion, which is the root of the term Zionism, has been used synonymously with Jerusalem since the early ages of Jewish history. The special meaning of this word was created after the destruction of the first Jewish temple in Palestine by the Babylonians; the term had become a treasure of emotion that accommodated the longings and desires of returning to Palestine for the Jewish people who expelled from their home Zion. Although it was used so early, the word "Zion" was first introduced into political literature by Nathan Birnbaum (1864-1937), a Russian Jew, in the last quarter of the nineteenth century, as a symbol of political thought. The foundation of the "Zion" (Hovevei Zion) organization lies in the thoughts of Yehuda Leib Pinsker, a doctor from Odessa (1821-1891), a Jewish intellectual. He argued that Judaism had not only a philosophy of belief but also elements of a nation. Especially since 1881, the Holocaust, which began in Russia, pushed Dr. Pinsker to the thought that Jews could not live together with other nations. That is, the Jewish communities that adopted his ideas formed local associations. This movement, which is known as "Zion lovers" in history, was rapidly developed in Russia and Eastern Europe, reaching 138 societies in 1890. See. Mim Kemal Öke, Siyonizm ve Filistin Sorunu (1880-1923), Timaş Pub. $7^{\text {th }}$ Edition, İstanbul 2018, pp. 38-47.

${ }^{11}$ Littman, "Saved from History's Black Hole".

${ }^{12}$ Ibid. 
and the other half were in up to 40 agricultural settlements in numbers. ${ }^{13}$ Sami Hochberg was included in the second of the aforementioned groups. After he went to Jaffa, he joined a group of settlers in Nahalat Reuven, south of Rishon Letzion. He forced his father to send him money to buy the land here. His two brothers, Peretz and Zvi, had planted vineyards here too. A few years later he returned to Bessarabia and went back to Palestine, taking his parents, four of his sisters and the entire capital money of the family. The Hochbergs settled in Nahalat Reuven and then to Wadi Hanin (Valley of the Roses) the name of which changed later to Nes Tziona ${ }^{14}$ ( $25 \mathrm{~km}$ South of Tel-Aviv). Hochberg was one of 12 founders who helped the families colonize and organize the agricultural work of the community. A non-biological grandson of him and an Israeli journalist Ygal Sarna (and Shany Littman who cited from him) ${ }^{15}$ compiled Hochberg's biography in Sokhen Mefukpak / Dubious Agent; and draws attention to the fact that today, Hochberg was a man with Israeli characteristics before the establishment of Israel and with an adventurous spirit whose name was engraved on a sign at one of the crossroads of the city. Despite his acquaintance and connection with the outstanding Zionist leaders, he was not one of them, but a leader in politics of the local dimension. ${ }^{16}$

The Hochbergs' life in Palestine did not start well financially. This financial challenge is not only specific to them, but as it is determined by M. K. Öke, it was almost valid for all Lovers of Zion who started colonization in Palestine because none of them had engaged in agriculture in the earlier stages of their lives. Due to this inexperience their financial resources melted and they were in desperately need even in a very short period. Without the famous philanthropist Baron Edmond de Rothschild who had extended his helping hand to Palestine, the dream of Zion could have gone down in the beginning. ${ }^{17}$

After the economic hardships faced by the Hochbergs consumed the family's savings, Sami Bey found a job as a teacher at the nearby Mikveh Israeli agricultural school and began living in the school's facilities with his first wife, Milka. Shumalit, Hochberg's first child was born here. But this child was not from his wife. The child was from another woman that Sami Bey met there. Shumalit died of an illness at an early age. Moreover, Sami Bey also lost his wife Milka because of a causeless suicide the reason of which was not reflected in the sources. After this suicide incident, he left for good not his profession as a teacher but $23^{\text {rd }}$ anniversary of his life and Nes Tziona ${ }^{18}$ where he had lived with his family in 1902 . He settled in Tiberias, about $60 \mathrm{~km}$ east of Haifa in today's Israel. Here, he continued to work as a teacher in a school that had connections with the organization Alliance Israélite Universelle. ${ }^{19} \mathrm{He}$ had a romantic

\footnotetext{
${ }^{13}$ See. Neville J. Mandel, “Attempts at an Arab-Zionist Entente 1913-1914”, Middle Eastern Studies, Vol. 1, Issue:

3, 1965, p. 239.

${ }^{14}$ Littman, "Saved from History's Black Hole".

${ }^{15}$ Yigal Sarna's mother (years before her marriage to Sarna's father) had her first marriage with Emile, the son of Sami Hochberg. For this reason, Sarna sees Hochberg as his non-biological grandfather. See. Ibid.

${ }^{16}$ Ibid.

${ }^{17}$ For more information on the difficulties Jews face in Palestine and the assistance in question, see. Öke, Siyonizm ve Filistin Sorunu (1880-1923), p. 49; Vahdettin Engin, Pazarlık, Yeditepe Pub. $22^{\text {th }}$ Edition, İstanbul 2018, p. 21 , 93-94.

${ }^{18}$ Sami Hochberg's grandchildren are in Paris today; the descendants of their brothers live in Ness Ziona. See. Littman, "Saved From History's Black Hole".

${ }^{19}$ The Alliance Israélite Universelle (AIU), is an organization founded in Paris at 1860 in order to modernize and renovate the Jews who live a poor and miserable life in various parts of the world and cannot keep up with the requirements of the era. For more information on that organization and its schools see. Neslihan Kuran, 19. Yüzyllda İstanbul'da Açılan Alliance Israelit Universelle Okulları, Selçuk University, Graduate School of Social Sciences, (Unedited) MA Thesis, Konya 2009, p. 1, cf. Naim Avigdor Güleryüz, “Alliance Israelite Okullar1,” Dünden Bugüne Ístanbul Ansiklopedisi, Vol. 1, İstanbul 1993, p. 206. Like Albert Benaroya, there were also prominent journalists
} 
relationship with Rosa Duek, who worked as a teacher at the same school. The couple married in Beirut in 1903. The newly wed couple went to Iran to set up Jewish schools for boys and girls as the ambassadors to the Alliance. The town of Senna (named as Sanandaj in Iranian Kurdistan today), $180 \mathrm{~km}$ north of Hemedan, was the new stop of Sami Bey. ${ }^{20}$

Sami Hochberg liked to live in luxury as it would be witnessed on the advancing lines. Though this situation is defined with the expression "extravagant" in the documents, in literature it is defined as "bills extending from day to day". Whatever the name is called, it is true that he was constantly struggling in an economic deficit. The fact that he requested financial aid from the Paris-centered Alliance Israélite Universelle organization and from his family through the letters he wrote is related to both the expenditures during the first colonization of Palestine and this luxurious life. What is interesting is that his family, without good economic conditions, were in anger and hostility towards him because of his pursuit of a career abroad. Sami Hochberg, in his letters to Wadi Hanin, constantly promised to help his family soon. In a letter he sent to his brother Tzvi in January 1904, he had mentioned that his family did not understand him, and that he was dependent on the complications of his life which had driven him to a distant country. At this point, it is to be noted that brother Tzvi Hochberg founded Nes Tziona's primary school in 1907 and that he was the head of the school for 24 years. ${ }^{21}$

In Senna, Sami and Rosa's eldest son, Theo was born. However, he was still struggling in the increasingly deep waters of the desperate financial strait. Moreover, he lost hope of getting support from his father. Now that he relied almost entirely on Israel Universelle, but the organization sent an inspector from Paris to Iran to oversee Hochberg's spending in Iran in 1908. Financial distortions were detected during the investigations. Hochberg was suspected to have been a fraud. He was dismissed as a result of the investigation. Thereupon, Hochberg was forced to leave Iran. This was how the five-year Iranian adventure, like the Palestinian one, ended with financial impoverishment and unemployment. He emigrated to Aleppo, Syria with his wife Rosa and his son Theo. Her second son Emile was born here. ${ }^{22}$

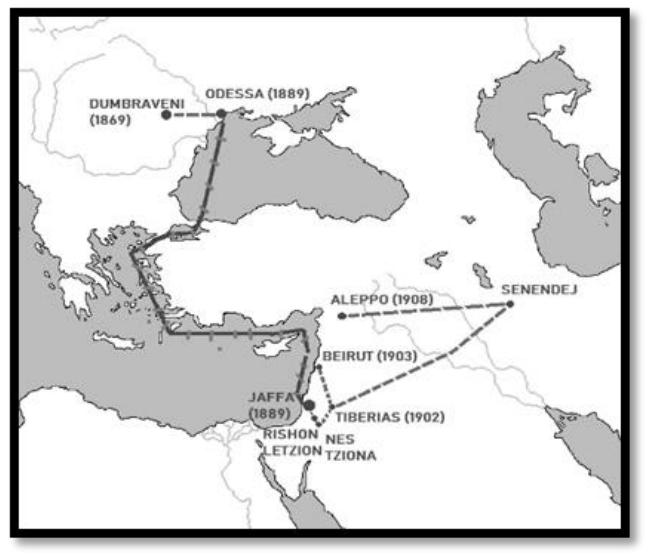

Figure I: Sami Hochberg's Life Map I - (1869-1889)

who have graduated from Alliance schools and have been teachers. See. D. Gershon Lewental, "Benaroya, Albert", Encyclopedia of Jews in the Islamic World, (Ed. Norman A. Stillman), Vol. I, Brill, Leiden 2018.

${ }^{20}$ Littman, "Saved from History's Black Hole".

${ }^{21}$ Ibid.

${ }^{22}$ Ibid.; Another source gave him the departure from Iran and went to İstanbul by Universelle, as a "duty". see. Encyclopedia of the Founders... 


\section{Hochberg the Journalist}

After the days of Iran, Sami Hochberg's migrant life did not end which is understood lasted very short but its not known how it passed. His stop was the Ottoman capital. He entered Istanbul without much glorious in 1909, where the celebrations of the second Constitutional Monarchy (23 July 1908) which assumed the role of a magnet for those like himself, continued. Hochberg has been placed not only in Istanbul but also in the Ottoman archives as if preparing the ground for this work. In fact, in the first year or two, he did not announce his arrival to archive staff and the ones benefitting from the archive in a loud voice. When he had a bash at the journalism and publishing industry, it ceased to be the work of a coincidence to come across to him from that moment.

Sami Bey soon established close contact with the Zionist circles in Istanbul. In this development, the British (Anglo) Levantine Bank's Istanbul branch had an undeniable contribution. The Bank was a work and an establishment of the World Zionist Organization. After Theodor Herzl (1860-1904), the rich businessman, David Wolffsohn (1856-1914), who was the second president of the organization, offered a considerable sum of $£ 2$ million to Sublime Porte in exchange for allowing Jews to settle in Palestine. Even though the Sublime Porte refused the offer, it allowed Zionists to open a branch of the British Levantine Bank in Istanbul as a gesture of goodwill. For the Zionists, this bank became their embassy of Istanbul, and Dr. Victor Jacobson, whom they brought to the head of the bank became their ambassadors. In fact, Jacobson is accepted as the Istanbul representative of the World Zionist Organization before Richard Lichteim. The first names Sami Bey had met in the Ottoman capital when the dust on his foot had not yet been wiped off were Dr. Jacobson, the director of the British Levantine Bank, and the deputy director Vladimir 'Ze'ev Jabotinsky. Jabotinsky was one of the young and ardent Zionists who came to Istanbul following the Second Constitutional Monarchy. These three new friends decided to publish a newspaper in order to encourage the Zionist interests and to convince the Ottoman rulers that the Zionists were loyal to the empire. ${ }^{23}$

Instead of building a new journal, they found it more appropriate to buy an old newspaper. In this direction, they headed to the newspaper named Le Courrier D'orient. This newspaper was published in Istanbul beginning from the 1860 s by French Journalist G. Giampiétri, a close friend of the new Ottomans. The newspaper none of whose copies reached today has been published by Ebüzziya Tevfik since April 1909. Ebüzziya was exiled to Konya in April 1900, and after the proclamation of the Second Constitutional Monarchy (July 1908), he returned to Istanbul, taking advantage of the general amnesty. Giampiétri died when he was in his exile. For this reason, the newspaper continued to be published jointly and in French by the heirs of Giampiétri and Ebüzziya. ${ }^{24}$ The interesting thing was the contrast between the editorial policy followed by the newspaper and the new suitors because the newspaper and the owner were on an anti-Semitic line. Now, three young Zionists were rushed to this newspaper with their fast flowing blood. As in the opening of the British Levantine Bank, Wolffsohn and of course his financial support was behind the youth again. ${ }^{25}$ In the summer of 1909 , the purchase was completed with his support, and the newspaper was handed over to a broadcasting committee composed of Sami and his friends. First, the name of the newspaper, then the broadcast policy changed. The only thing that hasn't changed was probably the language of the paper, French.

\footnotetext{
${ }^{23}$ Littman, "Saved from History's Black Hole”.; Öke, Siyonizm ve Filistin Sorunu (1880-1923), p. 80.

${ }^{24}$ Ziyad Ebüzziya, "Ebüzziya Mehmed Tevfik", TDV. IA, Vol. X, İstanbul 1994, pp. 375-378.

${ }^{25}$ D. Gershon Lewental, "Le Jeune Turc", Encyclopedia of Jews in the Islamic World, (Ed. Norman A. Stillman), Vol. III, Brill, Leiden 2018.
}

\section{History Studies}


The new name of the newspaper was 'Le Jeune Turc' (The Young Turk). It began to follow a pro-Zionist line pursuant to the aim of its purchase. In addition, as its name implies, the newspaper also included articles that support the Unionist government. This was a way for the government to give them permission to enable Jews to settle in Palestine. ${ }^{26}$

In a short period of time, the newspaper became one of the most popular publications in Istanbul with new names it incorporated. Apart from Jabotinsky, Dr. Jacobson, and Sami Bey, the first prominent name was to be Alexander Parvus, a Russian-Jewish origin. Parvus, a man in socialist thought, came to Istanbul in November 1910, following the Young Turk Revolution. According to N. Berkes, his ideas had been very influential on the Turkists and the leaders of Union and Progress. This was reflected in the congresses of the Union and progress in 1911, 1912 and 1913 and in the newspapers and magazines such as the French Jeune Turc and the Turkish Homeland (Türk Yurdu), which spread Turkism ideas. Ahmed Agayeff (Agaoğlu: 1869-1939) and Mr. Celal Nuri (Ileri - 1882-1938), with whom Parvus had connections in Istanbul, were also among the writers of Jeune Turc newspaper. ${ }^{27}$ In fact, Mr. Celal Nuri, one of the prominent figures of intellectual Turkish journalism, introduced himself as the "responsible manager" ${ }^{28}$ of the newspaper in a document encountered by chance in the Ottoman archives. A contemporary researcher has come to the conclusion about the relationship between the newspaper and Mr. Celal Nuri, whom he described as the preparer or founder of many newspapers of the time that 'Jeune Turc, founded secretly by the World Zionist Organization and published daily in French, was just one of the newspapers he dealt with.' ${ }^{29}$ Really, Dr. Jacobson agreed with Mr. Celal Nuri on writing articles in the newspaper in favor of Zionists and Jewish colonization in exchange for a thousand pounds per year. Celal Nuri remained faithful to the treaty and mentioned the benefits of Jewish colonization in Mesopotamia in his columns. ${ }^{30}$

Volume 12

The local and foreign writers mentioned did not write in the Jeune Turc Newspaper to make money. The basic element that united them under the roof of the newspaper was ideal and ideologies. These concepts, at least for the indigenous writers, were fed by historical competition and hostility. Understanding and making sense of this situation will help to illustrate not only the mission and vision of the newspaper with a sophisticated writer's staff but also the influence and traces of Sami Bey and the interest and breakthroughs in his life. As M. K. Öke quoted from Sir Gerard, the British ambassador in Istanbul, the Jews hated Russia and his government for a long time. Russia's friendliness in Britain since the first quarter of the twentieth century led Jews to be hostile to the British. As a matter of fact, the publication of articles in the Le Jeune Turc newspaper, which was often hostile to the British, and the fact that the newspaper, as if it were trying to enrage the English, constantly conflicted with the government of London, justified the ambassador. Especially Celal Nuri and Ahmet Agayeff wrote articles on February 1911 and took England against them. The fact that the Germans led the Jewish colonization in Turkey caused the British to see Zionists as agents used by Berlin who wanted to infiltrate the Middle East. Upon this discourse, On 10 May 1911, by Jacobson's suggestion, Wolffsohn made a statement in The Times that the Zionists pursued an independent

\footnotetext{
${ }^{26}$ Littman, "Saved from History's Black Hole".

27 About Parvus, known as Alexandre Helphand in Europe, and his writings see: Niyazi Berkes, Türkiye'de Çağdaşlaşma, Ed. Ahmet Kuyaş, YKY, İstanbul 2008, pp. 466-468; Mehmet Eröz, "Parvus'un Türkiye Hakkındaki Yazıları", İstanbul Üniversitesi İktisat Fakültesi Mecmuası, Vol. 43, İstanbul 1987, p. 347-356.

${ }^{28}$ BOA, DH. MUI., 143/23; 28 Mart 1328/10 April 1912.

${ }^{29}$ İlker Aytürk, "Celâl Nuri", Encyclopedia of Jews in the Islamic World, (Ed. Norman A. Stillman), Vol. I, Brill, Leiden 2018.

${ }^{30}$ Öke, Siyonizm ve Filistin Sorunu (1880-1923), p. 170.
} 
policy. It was emphasized that there was no intention to serve Germany's special interests and that the newspaper Le Jeune Turc was a pure Turkish newspaper, and in this respect, there is no responsibility for the Zionist Society due to the articles published therein. ${ }^{31}$

Besarya (Batzaria) Efendi Le Jeune Turc's, who was the Minister of Public Works in the cabinet of Mahmud Şevket Pasha, and about whom further information will be given in the following lines of the study as he will be met with Sami Hochberg in Bucharest was also one of the shareholders of the newspaper. During the Balkan wars, when the Bulgarians pressed in upon the lines of battle in Çatalca, he, together with the Foreign Minister Gabriel Noradunkyan Efendi, had a share in the stopping of Bulgarian progress with the false news that cholera had wandered in Istanbul. In his memoirs, he explained that he was one of the partners of the newspaper Le Jeune Turc: 'As far as I remember, I was called by Master Noradunkyan in one of the days when the Bulgarian cannon sounds were heard. Istanbul is being lost. Write a few articles in Le Jeune-Turc Newspaper. I was one of the partners of the newspaper ...,32

With the addition of Master Besarya, the main figures of the newspaper were completed. Sami Hochberg and his colleagues were also responsible for the control and publication of newspapers such as 'Le Bosphore Orient, Journal de Salonique and L'Epoca', which are in line with Le Jeune Turc. Together with Nahum Sokolow, they founded Ha-Mevasir (Mevasser) ${ }^{33}$, the only newspaper in Istanbul that was published in Hebrew, from scratch. This weekly newspaper was broadcast from 21 December 1909 to 3 December 1911. During the preparation process of the newspaper, Sami Hochberg and his assistant Aharon Hermoni had served most. ${ }^{34}$ Sami Bey, as it is seen, was freed from the clutches of the misery that had been stuck on since his youth, and in the first years of his life, he gave the impression of a publisher who was fully committed to journalism. Although its name was mentioned in many newspapers, it was almost synonymous with Le Jeune Turc. Anyway, Ottoman records referred to him sometimes as 'the owner of the newspaper, ${ }^{35}$ or sometimes an 'author' of this newspaper, and 'responsible manager' meaning responsible editor. Richard Lichteim, mentioned above as the representative of the World Zionist Organization in Istanbul after Jacobson, was recorded as the deputy of the Le Jeune Turc newspaper in one of the same documents. ${ }^{36}$

\section{Hochberg the Diplomat}

David Wolffsohn advised Dr. Jacobson whom he appointed as the head of the British Levantine bank that they should act very cautiously in Istanbul, not engage in political party strife and impose the Ottoman government that the Zionists had no problem with the Ottomans. As witnessed above, Jabobson and his friends either purchased or financially supported all the Jewish newspapers published in order to win the Ottoman public opinion in accordance with

\footnotetext{
${ }^{31}$ Ibid. p. $169-171$.

32 Cengiz Mutlu, Osmanlı'da Bir Ermeni Hariciye Nazırı Gabriel Noradunkyan Efendi, Gündoğan Pub., İstanbul 2015, p. 144.

${ }^{33}$ Stanford J. Shaw, Osmanlı Imparatorluğu'nda ve Türkiye Cumhuriyeti'nde Yahudiler, Trans. Meriç Sobutay, Kap1 Pub., İstanbul 2008, p. 285.

${ }^{34}$ D. Gershon Lewental, "Ha-Mevasser", Encyclopedia of Jews in the Islamic World, (Ed. Norman A. Stillman), Vol. II, Brill, Leiden 2018.

${ }^{35}$ BOA, DH.EUM. 5. Şb., 32/33; p.13 et al.; 15 Kanunuevvel 1332/28 December 1916; DH.EUM. 5. Şb., 81/12; p.1, 6, 11; 23 Nisan 1331/6 May 1915; HR.SYS., 2267/19; p.2; 3 May 1332/16 May 1916; HR.SYS., 2267/37; p.1; 18 August 1332/31 August 1916; HR.SYS., 2267/41; p.1; 28 August 1332/10 September 1916; BOA, DH.ŞFR., 71/115; 17 Kanunuevvel 1332/30 December 1916.

${ }^{36}$ BOA, DH.EUM. 5. Şb., 81/12; p.9, 11; 15 Nisan 1331/28 April 1915.
} 
the recommendations in question. ${ }^{37}$ In a short period of time, he began to process Zionism in the columns of many newspapers ${ }^{38}$ that continued their broadcasting life in Istanbul.

In order to keep the relations with the government in good standing, it was also noted above that Le Jeune Turc newspaper started to be written in the lines that supported the Government of Union and Progress and spreading ideas of Turkism. It is said that the newspaper was supported by the government based on these developments. Kamil Paşa, who could not get a positive response to his demands of loans from foreigners during the Balkan wars (1912/13) and who was struggling in financial impossibilities, had to apply to the Zionists and Jews as the last resort.

The Pasha supposed the Zionists would help the government in return for some privileges to be recognized in Palestine. Even before Kamil Pasha became grand vizier, in other words, before the dissolution of the Great Cabinet headed by Ahmed Muhtar Pasha, he had a conversation with Dr. Jacobson in September 1912 as the head of State Council. In an article sent to the Zionist Movement Committee by Dr. Jacobson on 7 October 1912, Kamil Paşa stated in this meeting that 'he did not see Zionism as a threat, but he would rather talk about the benefits of immigration and settlement to the country in both the State Council and the Cabinet.' After Kamil Pasha, Jacobson also met with Foreign Minister Gabriel Noradunkyan and found him very understanding of Zionism. In the words of Jacobson, these two Turkish ministers, who believed that the Zionists had great influence and power in Europe, wanted financial support from them and the government for support in the Western press because the Greeks who claimed that they had been subjected to the massacres of the Turks during the Balkan war had raised the European public opinion. In order to erase that kind of propaganda against the Turks, Kamil Paşa saw Sami Hochberg, the Editor-In-Chief of the newspaper Le Jeune Turc, which was funded by the Zionists on behalf of the government. ${ }^{39}$

Issue 4

August

2020

Towards the end of November 1912, Hochberg met with the Minister of Internal Affairs Mr. Reşid. The minister asked him to prepare a memorandum containing the aims and activities of the Zionists. He said the memorandum would be reviewed in the cabinet. Hochberg conveyed this meeting to Dr. Jacobson. Jacobson sent the requested memorandum to Reşid Bey on 6 January 1913. In those days, Kamil Pasha, who had been very close to them, became the grand vizier. It was obvious that the new grand vizier could easily influence other overseers during the discussion of the memorandum in the cabinet. Therefore, it was only a matter of time before the Zionists had their ambitions in Palestine. However, with the propaganda that the Kamil Pasha government lost Edirne to the enemy, Enver Bey and the ones accompanying him stepped on Babiâli and took the power again on January $23 \mathrm{rd}^{40}$

As evidenced by several occasions in the previous lines, the fact that the Unionists came to power did not make a radical change in the position of the empire in the face of Zionism. It was unlikely that they would be able to change the situation in a financial situation like that because the new government of Mahmoud Shevket Pasha was struggling in the grip of a material impossibility, like the previous ones. The Great Powers, whose door was knocked for salvation,

\footnotetext{
${ }^{37}$ Öke, Filistin ve Siyonizm Sorunu (1880-1923), p.146.

${ }^{38}$ For newspapers published by Hebrew and Jews in the Ottoman Empire see. Eli Haligua, "Yarım Asırdan Fazla Bir Süre Önce, Türkiye Yahudi Basınında İki Gazete", http://www.avlaremoz.com/2016/07/05/yahudi-basininda-ikigazete/ Access date: 11.12.2018; Shaw, Osmanlı Imparatorluğu'nda ve Türkiye Cumhuriyeti'nde Yahudiler, p. 283394.; for the Zionist-prone Jewish press see. Naim Avigdor Güleryüz, Türk Yahudi Basını Tarihi - Süreli Yayınlar, Gözlem Pub., $1^{\text {th }}$ Edition, İstanbul 2015, pp. 76-86.

39 Öke, Siyonizm ve Filistin Sorunu (1880-1923), p. 212; Mutlu, Osmanlı'da Bir Ermeni Hariciye Nazırl Gabriel Noradunkyan Efendi, p. 158-159.

${ }^{40}$ Öke, Siyonizm ve Filistin Sorunu (1880-1923), p. 213.
} 
gave the message that 'we are not at home'. The Unionists had no choice but to apply to Jewish banks and bankers. At this point, the Zionists could, at least, be a bridge between those institutions and the Unionists, mobilizing Jewish funds for the needs of the empire. The way to achieve this was to provide Zionists with some privileges in Palestine. This was extremely risky because the Unionists were also engaged in trying to extinguish the Arab nationalism, which had taken a flame in those days, by making some important concessions. Therefore, a move to the benefit of the Zionists in Palestine could lead to the burning of the flames. In this case, the only way out for the Unionists was to reconcile Arabs and Zionists. To ensure a convergence between the parties, Assad Pasha and Ahmet Agayef negotiated with Dr. Jacobson on behalf of Talat Bey. They talked to him about a 'Muslim-Jewish alliance'. For the Zionists, the offer sounded good. It was even regarded by Dr. Jacobson as an extraordinary opportunity because the Zionists finally understood the fact that the Unionists would not violate the Arabs and give Jews privileges in Palestine. If they could establish friendly relations with the Arabs, it would be easier to agree with the Unionists. In the face of this fact, they immediately plotted their arms to get closer to the Arabs. It was not hard for them to find a common enemy: Exploitation. After a short period of time, an article that advocated Jews to end the exploitation of the Christian world as a unity with Muslims had already met with the readers in L'Aurore, one of the Zionist media organs in Istanbul. ${ }^{41}$

The reader may have been struck by the perception that the researcher had lost track of Sami Hochberg in the triangle of the Unionists-Arabs-Zionists. However, it is necessary to point out that the triangle is created precisely and compulsorily in order to be able to continue its tracks and connections better and to convey its travel and activities in a meaningful whole. Giving an answer to the questions 'How was the Muslim-Jewish Alliance project the patent of which belonged to Talat Bey met in the Arab world?', Hochberg will be met again and it will be possible to follow him without any interruption.

Considering the developments, it is seen that the said project was adopted by Arabs too. As a reflection of this, the Arab Press began to include articles and messages in the importance and necessity of the Muslim-Jewish Alliance. Thus, the Arabs showed that they were ready to compromise with the Zionists. While the ink of those writings had not yet dried, a letter had fallen to Sami Hochberg's post box. The letter was signed by Ibrahim Salim (Sali) Najjar (Neccar) in the name of the decentralist Arabs. It was written to convey the desire to negotiate with the Zionists. Najjar also attached of the newspaper clippings about a possible alliance of debates reflected in the Arab press to the letter. Hochberg informed Dr. Jacobson of the initiative of the Arab nationalist and the Zionist Organization in Berlin. The organization agreed to negotiate with the Arabs. Jacobson elected Hochberg as a delegate and informed Zionist offices from this situation. Why was Hochberg preferred? In response to this, Mandel listed many reasons. Firstly, Hochberg had lived in Palestine for many years. He knew geography. He was no stranger to the language and culture of the Arabs. He could easily communicate with any group among the Arab communities. Later, he was the editor of a prominent newspaper (Jeune Turc) in the Ottoman capital. The relationship between the Ottoman politicians was good and they did not have any difficulty in accessing them. More importantly, he was not among the Zionist leaders. Naturally, the negotiations with the Arabs would not have an official dimension and meaning. ${ }^{42}$ Hochberg, who preferred such features, went to Cairo in April 1913 after receiving instructions from Jacobson. There he met the representatives of the El-La Merkeziye (Adem-i Merkeziyet, Decentralization). According to the

\footnotetext{
${ }^{41}$ Ibid. p. 213, 220-223.

${ }^{42}$ Mandel, “Attempts at an Arab-Zionist Entente 1913-1914”, p. 238, 243.
} 
reports he prepared and presented to his superiors, there was no certainty about the Jewish immigration to Palestine. Only two of the Arab leaders he met said they were against Jewish immigration. The Christian Arabs, who introduced themselves as minorities, expressed their satisfaction with the belief that Jewish immigration would provide economic prosperity and demographic balance in the region, meaning that no one would become a minority. In summary, Hochberg had a general impression that the Arabs were willing to cooperate with the Zionists. Before he left the city, he made an oral treaty with the Arab nationalists. As it can be easily predicted, the issues subject to this agreement were centered on the idea that the ArabJewish rapprochement was necessary. In principle, the Arabs would not oppose Jewish immigration to Syria and Palestine. The bad propaganda that dominated the Arab newspapers about this immigration movement would be stopped and a positive atmosphere would be created in favor of the Zionists. Likewise, the Zionists would make propaganda for the realization of the Muslim-Jewish alliance through the newspaper Le Jeune Turc and support the Arab nationalists as long as they did not damage the territorial integrity of the empire. ${ }^{43}$

Ahmad Bayhum from the Beirut Reform Committee also participated in the negotiations of Hochberg with the Decentralization members. Upon Bayhum's proposal and invitation of him "to speak with their own people in the same way and for an entente ${ }^{44}$, Hochberg came to Beirut on his way back to Istanbul, where he managed to make the same kind of conversation with the Arab nationalists. As N. Mandel noted, Hochberg had met a total of twenty people in Cairo and Beirut. Among them, almost all the nine people whose identities were determined were the separatist Arab leaders, who were journalists, committees or parties. ${ }^{45}$

In May and June, it was seen that the parties remained loyal to the agreement. The al-Ehram in Cairo and the al-Islah newspapers published in Beirut started to defend the idea that Jewish immigration would be beneficial in the Arab provinces. Besides, the Arabs accomplished to silence the anti-Zionist newspapers. Hochberg had also kept his word. Starting from May, Le Jeune Turc had published a series of articles under the name of 'Reforms in the Arab Provinces $^{46}$ and devoted a large part of its columns to the statements of the Arab nationalists. ${ }^{47}$ Hochberg drew attention to the view that 'both of the Arab organizations (The Decentralization Party and the Beirut Reform Committee) had no solid policies against Jewish immigration'. In his 12-page French report on 17 May 1913, which was reviewed by Eliezer Tauber, Hochberg mentioned the history of Arab nationalist movements, their attitudes towards Zionists and Jews, and their results. ${ }^{48}$

The Arab nationalists Congress, which convened in Paris between 18-23 June 1913 after Cairo, gave the parties the opportunity to know and understand each other more. Sami Hochberg was invited by the Arab nationalists as an observer to this congress. ${ }^{49}$ The Committee of Union and Progress sent his general secretary Mithat Şükrü (Bleda) to Paris to make a deal with the Young Arabs. Hochberg, who accepted the invitation, met with the parliamentarian of Hama, Abdülhamid Zöhrevi (Zühravi), who was the president of the Congress in Paris. Zöhrevi stated that it was not only desirable for the Jews to emigrate to Palestine, but it was a necessity.

\footnotetext{
${ }^{43}$ Mandel, “Attempts at an Arab-Zionist Entente 1913-1914”, p. 244-246; Öke, Siyonizm ve Filistin Sorunu (18801923), p. 225.

${ }^{44}$ Eliezer Tauber, “A Report on Arab-Jewish Negotiations During the Young Turk Regime”, Turcica, Issue 31, 1999 , p. 474.

${ }^{45}$ Mandel, "Attempts at an Arab-Zionist Entente 1913-1914", p. 244.

${ }^{46}$ Ibid. p. 246-247.

${ }^{47}$ Öke, Siyonizm ve Filistin Sorunu (1880-1923), p. 225

${ }^{48}$ Tauber, "A Report on Arab-Jewish Negotiations During the Young Turk Regime”, pp. 472-487.

${ }^{49}$ Öke, Siyonizm ve Filistin Sorunu (1880-1923), p. 225.
} 
According to Hochberg's notes, he was first presented as an enemy by Sheikh Ahmed Tabarrah, who spoke at the congress. However, this situation improved later. Moreover, Hochberg reported that there was not any trouble in Tabarrah's speech requiring the Jews to fear because his writing had been formally designed to be favorable. In conclusion, the Arab leaders stated that they could accept the immigration of the Jews to Palestine when certain conditions were met, such as the immigrant Jews conversion to Ottoman subjects. Dr. Hochberg was in constant contact with Jacobson who was in Berlin concerning the path and program that should be followed during the negotiations. Jacobson eventually arrived in Paris, and he, together with Sami Bey, talked the Arabs face-to-face. ${ }^{50}$ According to Ygal Sarna, the reason why Hochberg had a bad reputation among the Zionists is his report on what he saw as an observer in the context of this Congress and on the activities of Arabs who wanted to deal with the Zionists. ${ }^{51}$

After the congress, the name of Hochberg and his newspaper seems to have remained a little in the background in the triangle of Unionists, Arabs, and Zionists. Therefore, it was thought that it would harm the integrity of the study and thus, the narration of these developments in detail was avoided. It should be noted that even the fact that an interview of Congress President Zöhrevi was published in Le Jeune Turc is an indication that Sami Bey did his part in the reconciliation efforts of Arab and Zionists. In addition, on July 16, when the statement was published, the name of Le Jeune Turc was changed to 'L'union' exclusively for that day. Finally, after the congress, Zöhrevi, one of the Arap leaders, was hosted twice by Dr. Jacobson and Sami Hochberg in Istanbul and was warned that his overly friendly approach would not generate an extra return. ${ }^{52}$

\section{Hochberg the Publisher}

During the days of 1913, the ones in triangle were of two minds, the top decision-making bodies of the Ottoman Empire were discussing a petition signed by Sami Hochberg. Hochberg wanted to launch out a more important publishing life in a wider printing house under the umbrella of a company called 'the Ottoman printing company'. As stated in the petition, this company, based in Istanbul and with 16 thousand lira capital, would print and publish all kinds of books and booklets on a new printing press, as well as newspaper in every language. The details of the company's establishment and operation were also stated in the regulation attached to his petition. In Ottoman Empire, it was necessary to have legal permission, that is to say a licence $^{53}$, to establish a company, publish a newspaper or a book, or to open a printing press. As a matter of fact, Sami Bey wanted that permission to be granted to him for 25 years with the petition in question.

In the Empire, due to the dark political atmosphere of the era and the harsh censorship shaped by the atmosphere, the petitioners had to wait a long time for the result. Hochberg's attempt is not beyond this development either. As it is understood from the documents, he submitted his petition to the Ministry of Commerce and Public Works at the end of 1911. However, he had to wait almost a year and a half until mid-1913 to see that his request/petition had been placed on the agenda of the authorities who would give the final verdict. However, the request and the regulation were processed immediately by the Ministry of Trade and Agriculture, and the application file was referred to the General Directorate of Commerce for review. After making some corrections on the petition where necessary, the Directorate had

\footnotetext{
${ }^{50}$ Mandel, “Attempts at an Arab-Zionist Entente 1913-1914”, p. 248-250.

${ }^{51}$ Littman, "Saved from History's Black Hole".

${ }^{52}$ Mandel, "Attempts at an Arab-Zionist Entente 1913-1914", p. 249-251.

${ }^{53}$ Hümeyra Çelik, Başlangıcından II. Meşrutiyete Osmanlı Imparatorluğu'nda Basın, Süleyman Demirel University Graduate School of Social Sciences, (Unedited) MA Thesis, Isparta 2012, p. 70.
} 
returned the file to the ministry. On 25 November 1911, Hochberg's petition and regulation were presented to Prime Ministry ${ }^{54}$ from the ministry to appeal for further action, and a day later, they were referred to the 'State Council', whose primary duty was 'to examine all sorts of laws and regulations, and to arrange the reports'. ${ }^{55}$ Finally, on November 27, Sami Bey's regulation was handed over to the Ministry of Public Works and the Finance Department, one of the sub-committees of the State Council, where it would really be examined. This apartment was the source of the above-mentioned waiting process. In fact, on the sixth month of that waiting, on 1 May 1912, Hochberg presented a new offer to Prime Ministry, calling for the correction of the company's capital, which was previously registered as 16,000 Turkish liras, as 10,000 liras. $^{56}$

Many comments can be made regarding the aforementioned waiting process. If the concepts of identity and politics are kept away, this can be explained by the fact that the unit that would examine the petition was confronted with an excessive intensity of applications triggered by concepts of thinking and writing freely brought about at the beginning of constitutional monarchy, and their old habit of a bit too rigorous review. However, when the concepts of identity and politics are taken into account, different interpretations will emerge. For example, the developments that took place between the Unionists, Arabs and Zionists may have been the source of this expectation. In fact, they were because Hochberg and his friends had intensified their close relations with the government of Kamil Pasha and his later established Unionist government at the end of 1912, and at the beginning of 1913. Besarya Efendi, about whom it was mentioned that he wrote for Le Jeune Turc Newspaper and he would be seen with Hochberg later, had already taken his place as the Minister of Public Works in the new Cabinet. He also had his signature under the decision to be reached a little later in the Ottoman Council of Ministers (Private Assembly of Deputies / Meclis-i Mahsus-ı Vükelâ) on the petition of Hochberg. Finally, Hochberg's petition and regulations were put to the table on 2 April 1913, with the proposal of Mr. Talat's 'Muslim-Jewish alliance'. Hochberg's participation in the National Congress of Arab Nationalists in Paris as a delegate of Zionists was also at the beginning of this month. The fact that all these developments, together with a political compromise and cooperation, gained a vital dimension for the Union, and that the possibility of a flow of Jewish funds in the direction of the Ottoman Treasury appeared on the horizon make it more likely that Hochberg's petition had a direct impact on the process and a positive decision on the issue.

It is possible to extend the possibilities, however, if the truth is to be restored, as is just stated, Hochberg's petition was read and examined by the members on the second day of April 1913 at Department of the Public-Education and Finance of the Council of State. Some amendments were made to some of the clauses of the company regulation which was presented together with the petition, in accordance with the requirements of the business and situation, and in terms of spelling. In addition, in accordance with the petition submitted later by Mr. Sami, the company's capital is fixed at '10 thousand Liras'. After these procedures, a clear copy of the regulation was presented to the Council of State. ${ }^{57}$ This was also a precursor to a new bureaucratic adventure for the revised regulation. One day later, the first stop was the Ottoman Cabinet (3 April). As a result of the reviews made here, it was decided that the amendments made by the Council of State were in place and it was appropriate to submit the

\footnotetext{
${ }^{54}$ BOA, SD, 3115/1; 12 Teşrinisani 1327/25 November 1911.

${ }^{55}$ See. Mehmet Canatar-Yaşar Baş, "Şura-yı Devlet Teşkilatı ve Tarihi Gelişimi”, OTAM, Iss. 9, Ankara 1998, p. 117.

${ }^{56} B O A, S D, 3115 / 1 ; 18$ Nisan 1328/1 May 1912.

${ }^{57}$ BOA, I.MMS., 163/15; p.2a; 20 Mart 1329/2 April 1913; BOA, ŞD, 3115/1; 20 Mart 1329/2 April 1913.
} 
required authorization to the petitioner. Now, only the approval of the Sultan was left for the regulation to gain a legal character. For this purpose, the Petition Department of the Council of Ministers (Maruzat Kalemi) prepared a statement of will. ${ }^{58}$ The explanatory document (Layiha), which included the announcement of the Ottoman printing company as a joint stock company', was presented to the palace together with the record regarding the interview and company regulations. With the declaration that 'the Minister of Trade and Agriculture is responsible for the execution of this will', it was approved by the Sultan on 6 April 1913 and sent to Prime Ministry. ${ }^{59}$ Finally, all the decisions and documents related to the company were referred from the Prime Ministry to the Ministry of Trade and Agriculture on 14 April 1913, for further action. ${ }^{60}$

With the completion of this intensive bureaucratic traffic, Sami Hochberg was now able to establish the Ottoman Printing Company and complete the legal permits required to operate it for at least 25 years. The issues such as how the company will be set up and how it would operate were dealt with in detail in the company charter, consisting of 7 chapters and 45 articles. For example, the company would consist of a Board of Directors and a delegation. The company's headquarters would be in Istanbul, but the branches of the Ottoman country could be found in another location or in foreign countries. The capital was 10 thousand liras. Within the scope of this capital, 10 thousand shares, each worth one lira, would be created, these shares would not only be shared among the members of the Board of Directors of the company and the general committee but would also be publicly traded with the announcement. Many details such as what would be the fate of the bills, the members and functions of the Board of Directors and the general committee, the reserve fund to be created and the conditions under which it would be used were among the elements that constituted many of the regulations. ${ }^{61}$

\section{Hochberg the Zionist}

As we have seen, Sami Hochberg had the fruit of the long bureaucratic wait. Now he would be able to publish newspapers in all languages and print all kinds of books and booklets via his company, which he would establish on a hundred percent legal basis. But it wasn't like that. The documents and the silence of the literature, for the time being, indicate that the company's story was not completed in 1913. There is no such possibility for the next year anyway, in 1914, it was as if all negativity had been imposed on Sami Hochberg. First, his 76-year-old father Mordecai Hochberg's death was reported from Nes Tziona. Moreover, father Hochberg was sent to his last journey in anger and anger towards his son, among the reasons of this the separation of Palestinian territory and the loss of family financial funds occupy the first place. ${ }^{62}$

The first World War (1914-1918), which broke out when he was mourning his father, left no trace of Sami Hochberg's identity as a journalist and presser. When mobilization songs began to be heard in the empire the Martial Government (Hükümet-i Askeri) and the Martial Court (Divân-ı Harb) closed his newspaper Le Jeune Turc. Litmann pointed out that the newspaper

\footnotetext{
${ }^{58}$ For the will report, see. $B O A, M V ., 231 / 45$; 25 Rebiyülahir 1331/3 Nisan 1913.

${ }^{59}$ BOA, I.MMS., 163/15; 24 Mart 1329/6 Nisan 1913.

${ }^{60}$ BOA, BEO, 4163/312224; 1 Nisan 1329/14 Nisan 1913.

${ }^{61}$ BOA, I.MMS.163/15; p. 2a-6b.; Exactly or in a way to make a transfer of this regulation will be an obvious threat to the volumetric limits of the article so Hochberg's company regulations have been decided to be offered to the benefit of the scientific world in a separate study see. Ahmet Yüksel - Okan Güven, "Building an Image in Each Language with Jön Türk Newspaper Manager Mr. Sami: Ottoman Publishing Company", Science Beyond Boundaires II - Thematic Collection of Papers of International Significance, Universitet i Priştini Filozofski Fakultet, Kosovska Mitrovica 2019.

${ }^{62}$ Littman, "Saved From History's Black Hole".
} 
was closed within the framework of general measures procedures in the Empire. ${ }^{63}$ There is no sign of exactly when and in what way the closure action took place. They now refer to Sami Bey only as 'abolished' or as the director and concessionaire of the abolished ${ }^{64}$ or closed $^{65}$ Young Turk Newspaper. At this point, M. K. Öke's evaluations are important: 'Despite all the good intentions of the Unionists mentioned above, the Zionists did not keep their promises to the Sublime Porte. They had not made any efforts to acquire Ottoman citizenship and preferred to remain in their foreign nationality. Secondly, there was not any attempt to provide financial assistance, which was the main reason for the optimistic policy pursued against them, which the Unionists were eagerly awaiting. The abolition of the prohibitions against Jewish immigrants had no positive return to the government and angered the Arabs further. For all these reasons, the Unionists made an immediate return in their politics and reinstated the prohibitions and restrictions that were imposed to prevent the Zionists' activities in Palestine during the reign of Abdülhamid. When the anti-Zionist prohibitions began to be applied again, Rabbi Nahum and Mazliyah $^{66}$, who applied to the union of Union and Progress Society, were scolded by Talat Bey and Mithat Şükrü Bey on behalf of the Union when they tried to protest the situation. They were given the answer that the main reason for the re-enactment of these prohibitions was that the Zionists did not stand in their words. Lichteim conveyed this to the Zionist Movement Committee on 17 June and 28 July 1914'.67

It appears that in the days when World War I began and the Ottoman Empire was not yet involved in that war, the Union began to create insuperable barricades between the Zionists and them. What happened to Hochberg and his newspaper was not outside the transformation of the Unionists' policies. As a result of the mentioned process, legal prosecutions began in Istanbul against the Zionists. Almost all the people in question, especially Hochberg, have been mentioned in this work in some way. The document with 'private' code and titled as 'about Zionist deeds and chefs ${ }^{68}$ in İstanbul' which was sent On 26 April 1915 from Ministry of the Interior General Directorate of Security Affairs to General Directorate of Police Forces is ready to witness to what happened. Here, it was demanded by the military government that the characteristics and nationalities, if they have changed their nationality, the date of the change, related to the following people be investigated and urgently reported: Hochberg, the director of the French Le Jeune Turc Newspaper, whose publication was suspended (sed), and then closed; its deputy director, Lichteim Anglo (English); Manager of Levanten Bank, Dr. Jabobson; Owner and director of French L'aurore newspaper; Lucien Sciuto ${ }^{69}$, and other persons composing the editorial board, and finally, Parvus, Dr. Isak Yuvana, and a lawyer who were later searched by the Police Department in their homes. ${ }^{70}$ This article is the official document

\footnotetext{
${ }^{63}$ Ibid.

${ }^{64}$ There are different dates in the literature regarding the years in which the newspaper was published. e.g. S. Shaw noted that the paper was published by Sami Hochberg between 1908 and 1918. see. Shaw, Osmanll Imparatorluğu'nda ve Türkiye Cumhuriyeti'nde Yahudiler, p. 285. Another source stated that Le Jeune Turc was active between 1909 and 1915. see. Güleryüz, Türk Yahudi Basını Tarihi - Süreli Yayınlar, p. 82.

${ }^{65}$ BOA, DH. EUM. 5. Şb., 32/33; p.57, 59; 7 Nisan 1332/20 April 1916.

${ }^{66}$ Nissim Masliyah is one of the most active names of Jewish intellectuals in Salonica, who adopted the idea of Ottomanism. After the Revolution of 1908 he came to Istanbul and was elected as deputy of İzmir to the parliament for Committee of Union and Progress. see. Melih Çoban, "Ottoman Jews in Salonica: A Community At The Heart Of Ottoman Enlightment”, Turkish Review of Balkan Studies, Vol. 11, 2007, p. 81-82.

${ }^{67}$ Öke, Siyonizm ve Filistin Sorunu (1880-1923), p. 236-237.

${ }^{68}$ See. Annex 3.

${ }^{69}$ Lucien Sciuto (1858-1947) was born in Thessaloniki. He published the weekly newspaper L'Aurore, which reports on the Jewish community, initially in Istanbul and after (1922) in Cairo. see. Shaw, Osmanlı İmparatorluğu'nda ve Türkiye Cumhuriyeti'nde Yahudiler, p. 285.

${ }^{70}$ BOA, DH. EUM. 5. Şb, 81/12, p. 11; 13 Nisan 1331/26 April 1915 .
} 
that the Unionist government was holding a relentless battle not only the enemy on the fronts, but also with the Zionists in the capital. Hochberg also seems to have escaped with his newspaper and printing house in that war as seriously wounded. However, he and his friends not only attracted the wrath of Unionists but also they got their sleuth after them.

The documents produced one after another are ready to witness the last development. For example, two days after the Police manager signed the above request of the General Directorate of Security, an answer was written on 28 April 1915. With this, the information obtained as a result of the investigation carried out about the Zionists was conveyed. Sami Hochberg was again in the first place: he is the director of the Le Jeune Turc Newspaper, which was repudiated by the military government. He is from Ottoman subjects. His father's name is Mordechai. Richard Lichteim is the Acting Director of the newspaper. He became a German citizen and had to stop working for the Le Jeune Turc administration about a month before he began to work at the German embassy in Istanbul; It was learned that Dr. Viktor Jacobson who was the director of British Levantine Bank came to Istanbul on 11 April 1915 with a German passport. Lucien Sciuto, who was the owner and director of the French L'Aurore newspaper, was from the Jews of Thessaloniki and Ottoman subjects; it was understood from the investigation that he personally saw all the works of the newspaper he published, and he did not have an editorial board either. As for Dr. Yuvan, he was a Russian national and went to Russia on the declaration of the war. It was also verified that the last mentioned lawyer was a Russian citizen of the Polish Jews, and Parvus was the Hungarian. ${ }^{71}$ This is the information obtained as a result of the investigation conducted by the police directorate. Among those, the most striking one in terms of this study is that of Hochberg's nationality. It was noted that he was an Ottoman citizen. As it can be witnessed soon, he made such a statement in 1916. In addition, this situation is noticeable in the documents produced during the war years. ${ }^{72}$ On the basis of this development, Under the proposal of the Jewish-Muslim alliance, it can be concluded that one of the conditions that Mr. Talat ran for the Jews who wanted to obtain privileges in Palestine was met by Hochberg.

Whether or not Sami Hochberg was an Ottoman citizen, he was now a Zionist, and was followed by the Ottoman authorities, especially by intelligence units, even though it was not a technical follow-up. Especially after the closure of his newspaper, he must have attracted the attention of the Ottoman units because of his travels abroad, which took an important place in his life. This situation is consistent with both documents and literature. In the literature, it was recorded that after his newspaper was closed, he sent his wife and child to Bucharest, and he was now serving Germany as a spy, so he frequently shuttled between Vienna, Berlin, Bucharest and Istanbul. ${ }^{73}$ The issue of his espionage had not been raised for a long time in records, so it was not yet been discovered by the Ottoman intelligence units, because Mr. Sami would travel to the mentioned cities by using his family and printing press as an excuse, and continue his life in Istanbul under the shade of an unspecified suspicion. But as far as it can be measured from the documents, the doubt about him tends to rise steadily. For example, after about a week after the last correspondence shared above (on 4 May 1915), the Directorate of Security of the Ministry of Internal Affairs requested that not only the 'Zionist Sami', who was reported to have returned from Bucharest in those days, but also the people with whom he had

\footnotetext{
${ }^{71}$ BOA, DH. EUM. 5. Şb, 81/12, p. 6, 9; 15 Nisan 1331/28 April 1915.

${ }^{72}$ It is possible to see in many documents that Mr. Sami was an Ottoman Subject (Tebaa-i Osmanîye): BOA, DH. EUM. 5. Şb., 32/33; p.25, 47, 51, 57; 14 September 1916; BOA, DH.EUM. 5. Şb., 22/28; p.3; BOA, DH. EUM. 5. Şb., 81/12; p.4, 9; 13 May 1332/26 May 1916; BOA, HR. SYS. 2267/37; p.1b; 18 August 1332/31 August 1916; From the Ottoman People, see. BOA, DH. EUM. 5. Şb., 32/33; p.59. 7 Nisan 1332/20 April 1916. See. Annex 4.

${ }^{73}$ Littman, "Saved from History's Black Hole".
} 
contacted be investigated. ${ }^{74}$ The Police Department, which was the addressee of this request, was prepared for Mr. Sami again. In fact, in the reply written two days later it was recorded that the investigation carried out led to the findings that Sami Hochberg returned to Bucharest on 24 April 1915, and moved to Kroker Hotel on 24 April 1915, when these lines were written. ${ }^{75}$

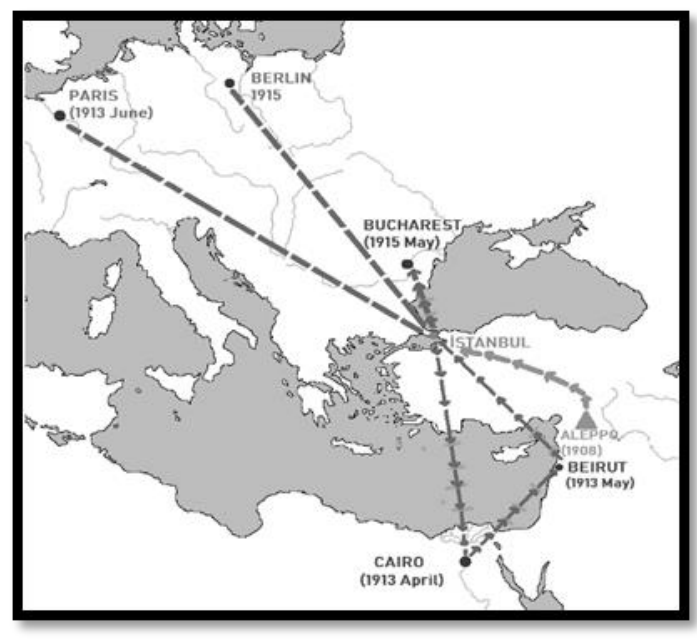

Figure 2: Sami Hochberg's Life Map II - (1908-1915)

\section{Hochberg the Spy}

As seen, Sami is now followed step by step. In the literature, it is this follow-up that provides the filling of the gaps in the part of his story at least related to the Ottomans. Moreover, the fact that he was constantly showing up outside the borders of the empire did not cause any decrease or loosening in the follow-up's frequency and firmness. For example, it should be ordered to Allied Germany to follow up on what he had been eating during his last trip to Bucharest because at the beginning of the year 1916, an intelligence report on Sami Hochberg had arrived from the German naval range commander to Deputy Commander in Chief of the Ottoman Army. ${ }^{76}$ According to the information contained in the report, the Germans were very generous about Sami Hochberg, whom they presented as the Jewish citizen of Ottoman from İstanbul. So much more detailed and striking information from her appearance to lifestyle had been given too. This, of course, is a very satisfactory development in terms of researching and reader of him. However, it is doubtful whether Mr. Hochberg would be a partner of this satisfaction or not. Because he is referred to as ' $f a t$ ' in the document. Short length, dark skin, black and sharpened mustache, and beard are the other physical definitions related to him. ${ }^{77}$ Based on these definitions, it is possible to draw a police sketch of him. Fortunately, the presence of the following photo does not require such an attempt. The noteworthy point in the photograph is Hochberg's thin portrayal as if to deny the records. However, the photograph belongs to his youth years. He was at the age of 47 when the document was created. Reminded of the truth that he was someone who likes to spend money and therefore likes to eat, his weight should have advanced with his age.

\footnotetext{
${ }^{74}$ BOA, DH.EUM. 5. Sb., 81/12; p.6; 21 Nisan 1331/4 May 1915.

${ }^{75}$ BOA, DH.EUM. 5. Şb., 81/12, p.1; 23 Nisan 1331/6 May 1915. (The letter sent to the Ministry of Internal Affairs from the $3^{\text {rd }}$ branch of the politic section of İstanbul Police Department of the General Directorate).

${ }^{76}$ BOA, DH.EUM. 5. Şb., 81/12, p. 4.

${ }^{77}$ BOA, DH.EUM. 5. Şb., 22/28; p. 3; BOA, DH. EUM. 5. Şb., 81/12; p. 4; 13 May 1332/26 May 1916.
} 


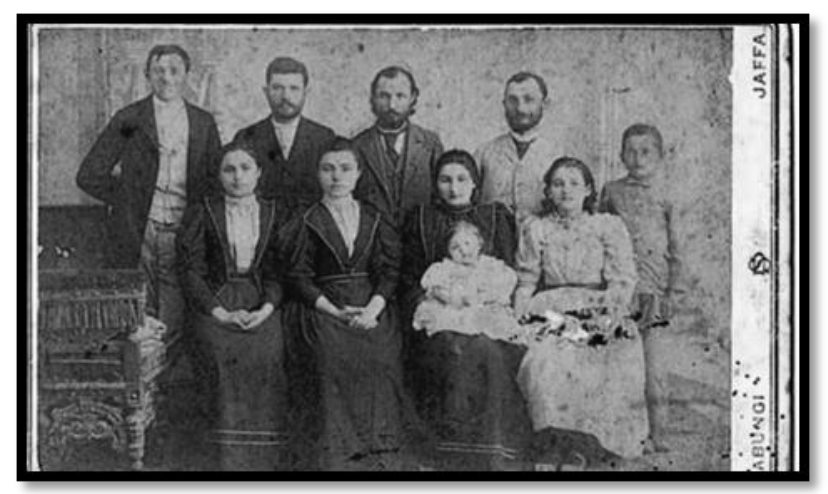

Figure 3: Hochberg Family Photo Taken at the Late Nineteenth Century in Jaffa (Sami Hochberg is in the Middle) ${ }^{78}$

If a large part of the above physical identification and inferences, which can be perceived as unnecessary, are left aside and returned to the report of the German intelligence, the following statements are encountered: He was staying in room 151 at the Grand Hotel in Bucharest for several months, claiming to be a Turkish journalist. He frequently traveled to Vienna, Berlin, and Istanbul. He lived an extremely luxurious life. He was dressed nice. For example, he had a fur coat on him at the time. He was staying in one of the best rooms in the Grand Hotel. He made constant expenses. He was very generous. He met with some Russians very often. He was communicating with them in German. In particular, he frequently met two people from the Jews of Russia, who stayed in rooms 100 and 150 next to his room. They were 30-35 years old. They were both brunettes, short, shaven and beautifully dressed. They also spent a lot of money, and they had a meal with Sami at the modern and continental restaurants. During the interviews with some Russians, they were posing as engineers. There was a great deal of sincerity among these three people. They received letters and money from other countries. They were opening the communication documents together. ${ }^{79}$

As reflected in the report, Sami Hochberg prefers the best room in the hotel where he lives, modern restaurants for food, and expensive clothes such as fur for clothing. It was mentioned before that due to his love for luxury living and spending money, his bills extended day by day and floated in a constant economic dilemma. As far as the people he was in contact with in Bucharest were probably the Russian leg of the Zionists who served the Germans as a result of the historical hostility and anger fed by the Russians. The interesting thing about the content, even the existence of the report, is the fact that Sami Hochberg was marked and journaled by the Germans to the Ottoman authorities even though he was serving as a spy. Those who did this are the ones on the German military wing. German diplomats are the ones who use Hochberg as a spy, as will be stated below by himself. This should be the underlying reason of the interesting point. The German Diplomats must have avoided sharing the name of Sami Hochberg, who serves as a spy by fulfilling a requirement of intelligence, not only with their allies who were the Austrian and Ottoman Empires but also those even attendants of the German Army.

The information gathered on Hochberg by the German Naval Range Commander consists of the above one shared above because he had recently returned to Istanbul as confirmed by the sources. The interlocutor of the report prepared by the Germans was the General Intelligence

\footnotetext{
${ }^{78}$ For the source of photography see. Littman, "Saved from History's Black Hole".

${ }^{79}$ BOA, DH.EUM. 5. Şb., 22/28; p. 3.
} 
Branch of the Head Command. On 21 March 1916, the Branch sent a copy of the report to the Directorate of Security of the Ministry of Internal Affairs and a copy to the General Directorate of Police. These units would continue the investigation into Sami Hochberg and convey the information to the Headquarters. ${ }^{80}$ Therefore, on 28 March, the police started a new investigation. The investigation lasted for 20 days and the information was transferred to the Ministry of Internal Affairs on 17 April $^{81}$ and to the Headquarters on 20 April. ${ }^{82}$ In the light of the information obtained as a result of the investigation carried out by the Ottoman agents, Sami Hochberg is a 45-year-old Ottoman citizen. Previously, he lived in Kürekyan Apartment Building in Ayaz Pasha's Small Cemetery Street. The move to the 23rd district of Hüseyin Ağa neighborhood in Beyoğlu was a later movement. After sending his family abroad, he had settled in Kroker Hotel alone. After this information about the places where he lived, the report mainly draws the first stages of the road map of Hochberg's route abroad. For example, it was recorded that he sent his family to Bucharest when the war started, went to Berlin on 2 February 1915, to supply the paper, and from there he returned to Istanbul, and finally went to Bucharest to visit his family. It was stated that he was still there as of 20 April 1916, when this report was written. ${ }^{83}$

As you can see, the suspicions regarding Hochberg did hit the peak on the Ottoman side. However, no evidence of the possibility that he might be a spy was reflected in the documents. Hochberg continued to travel abroad with the pretext of supplying paper or seeing his family as a printer in those days when the dust clouds removed by the war left no sign of his publisher identity. However, the name Sami Hochberg would suddenly be subject to a very intense interstate correspondence traffic, though it had not yet been two months since the last investigation report on him. The mentioned traffic begins with a telegraph ${ }^{84}$ dated 9 June 1916 from the Ottoman embassy in Vienna to the Ministry of Foreign Affairs. According to the telegram, which was presented to the minister of interior, Talat Bey on 14 June with the signature of the minister of foreign affairs, Halil Bey, Sami Hochberg was arrested in Brashov (Brasso) by Hungarian officers on suspicion of being spies and Serbian subjects. For this reason, Sami Bey asked to be patronized by the Turkish authorities with a telegram he sent to the Ottoman embassy in Vienna. However, before making any attempt, the embassy sought to obtain information about Sami's identity and asked the Foreign Ministry to apply to the Ministry of Interior for that purpose. ${ }^{85}$ Upon this application, the Ministry of Internal Affairs immediately made a new investigation about Sami Bey and as a result, very striking information was obtained. According to the information which was sent by the signature of the Ministry of Internal Affairs by Talat on 26 June 1916 as a response to the Ministry of Foreign Affairs, Mr. Sami was a companion of a Zionist community. In fact, it was understood that he was a pernicious person who had carried out the duty of the trustee of the İstanbul branch of the association sometimes. His newspaper was also repealed by the Martial Court during the mobilization. He in response went to Bucharest and worked there for Zionism with all his strength. Then, he traveled to the countries of the Entente States and even carried out

\footnotetext{
${ }^{80}$ BOA, DH.EUM. 5. Şb., 22/28; p.1; 8 Mart 1332/21 March 1916; BOA, DH.EUM. 5. Şb., 81/12; p. 4; BOA, DH.EUM. 5. Şb., 32/33; p. 57, 59.

${ }^{81}$ BOA, DH.EUM. 5. Şb., 32/33; p. 57; 4 Nisan 1332/17 April 1916.

${ }^{82}$ BOA, DH.EUM. 5. Şb., 32/33; p. 57; 7 Nisan 1332/20 April 1916.

${ }^{83}$ A Letter which was sent from the İstanbul General Police Directorate politic section $3^{\text {rd }}$ branch to the Internal Affairs: BOA, DH.EUM. 5. Şb, 81/12, p. 1; 23 Nisan 1331/6 May 1915; With the signature of General Police Chief and code of 'secret' a letter sent from İstanbul General Police Directorate politic section $3^{\text {rd }}$ branch to the Internal Affairs: BOA, DH.EUM. 5. Sb., 32/33; p.57, 59; 7 Nisan1332/20 April 1916.

${ }^{84}$ The original text of the Telegraph in French exists. see. BOA, HR. SYS, 2267/19, p. 1.

${ }^{85}$ BOA, HR.SYS, 2267/19; 1 Haziran 1332/14 June 1916.
} 
propaganda activities to meet with the senior executives of the enemy states and to ensure that the Palestinian Question was taken to the agenda of the Independent Peace Congress. In the words of Mr. Talat, all these issues have been affirmed by various sources and therefore he is not worthy of patronage by the Vienna embassy. It is not appropriate for such a person to return to the Ottoman country at that moment. This is how the situation should be conveyed to the embassy of Vienna. ${ }^{86}$ On 28 June 1916, Minister of Foreign Affairs Mr. Halil exactly transmitted Mr. Talat's response to the Ambassador of Vienna, Hüseyin Hilmi Pasha. ${ }^{87}$

It is important to point out an important issue here immediately before moving on to the following developments. It is the fact that Talat Bey's letter is fed by the wrong intelligence channels, as the continuation and the end of the story is well known. This finding is no longer valid for Hochberg's Zionism axis and purposeful activities, many of which have already been touched above. The misinformation relates to his search for mediation and support of the Entente States for the solution of the Palestinian Problem because many of the Zionists trust Germany, not just Sami Bey, and that's why Sami serves the Germans. But with the reply of Talat Bey, the road to Istanbul seems to have been closed for Sami to not open again. However, The French memorandum (notice) which was sent by another ally of the Sublime Porte, Istanbul Embassy of the Austro-Hungarian Empire to the Ministry of Foreign Affairs on 31 August 1916, with the title of 'extremely secret and urgent' would completely reverse the situation. According to the memorandum, when Sami Hochberg was captured, he stated that he was going to Romania to work for the interests of those states, promising Transylvania to the Government of Bucharest on behalf of the Central Powers (Germany and Austria-Hungary). That's why he was banned from travel and arrested. As a result of the investigation by the Austrian authorities following the arrest, important information was obtained about the activities carried out by Hochberg in the past and his activities touched on for a variety of reasons within this study. That he had previously worked for the Alliance Israélite Universelle community in Iran and Russia and he was the editor of the Young Turk Newspaper were revealed, as Austrians say. However, there was not enough evidence to require him to be referred to the courthouse. However, the Austrian army chief commander of the AustroHungarian army prevented Sami Hochberg from going to Romania and the situation was forwarded to the Austrian government. Finally, the government decided that Hochberg, who was apparently a member of the Ottoman population, was sent to Bulgaria and handed over to the Ottoman border officers. According to their estimates, Hochberg would have reached the Ottoman-Bulgarian border in early September. The allies' request from the Ottoman government was to prevent them from leaving the Ottoman country, at least until the war ended, so that the name, which is now at the heart of international suspicion, would be accepted from the border and could not attempt similar provocative actions. Ministry of Foreign Affairs translated the memorandum as soon as they received it and on the same day, they added 'urgent

\footnotetext{
${ }^{86}$ BOA, DH.EUM. 5. Şb., 32/33; p. 55; 13 Haziran 1332/26 June 1916; BOA, HR.SYS, 2267/23, p.1; 13 Haziran 1332/26 June 1916.

${ }^{87}$ HR.SYS. 2267/23, p.1; 15 Haziran 1332/28 June 1916; that document has been used by many researchers to emphasize the strict precautions which were taken by the government of Union and Progress for the Zionism during the war. see. Mehmet Mahfuz Söylemez, "Kudüs ve Osmanlı Arşiv Vesikaları Işı̆̆ında Yahudilerin Bölgeye Yerleşmeleri Üzerine Notlar”, Siirt Üniversitesi Illahiyat Fakültesi Dergisi, Vol. 1, Iss. 2, 2014, p. 51; Mehmet Mert Çam, "Birinci Dünya Savaşı'nda Filistin'deki NİLI Ajanları'nın Faaliyetleri”, Yeni Türkiye, Iss. 86, Ankara 2016, p. 288; Mustafa Murat Çay, Cevat Rifat Atilhan - Askerî, Siyasî ve Fikrî Yönleriyle, Selçuk University Graduate School of Social Sciences, (Unedited) PhD. Thesis, Konya 2013, p. 108.
} 
and secret' expressions in it again and sent it to the Internal Affairs Ministry by requesting that the requirement be made. ${ }^{88}$

Mr. Talat, who had just rejected the return of Hochberg to the country in a certain and sharp manner, did not raise any voices at all this time. On the contrary, he immediately informed the Police Inspectorate at Uzunköprü that Sami Hochberg, who would soon be at the frontier, should be taken from the border. He also communicated to the Foreign Ministry on 10 September 1916, that the request from the Allies had been fulfilled in this way. ${ }^{89}$ Meanwhile because of his work for the benefit of enemy governments, a decision was taken to banish him to a suitable place within the country as soon as possible. This decision was submitted by the Fifth Branch, one of the offices of the Ministry of Internal Affairs, to the Navigation Department on 7 September. What the branch had to do was to bring Sami Hochberg, who would soon reach the Ottoman-Bulgarian border, to Istanbul under the supervision and hand him over to the Police Directorate. ${ }^{90}$

As preparations for making Istanbul more uninhabitable for Sami Hochberg continued, the Austrian Embassy in mid-September reported that he had been transported to Bulgaria. On 27 September 1916, the Ottoman Empire's Sofia military attaché contacted the Bulgarian government on the extradition of Hochberg in accordance with the order of the Ministry of Foreign Affairs. ${ }^{91}$ Following the negotiations, Hochberg was finally handed over by the Bulgarian authorities to the Ottoman border officers at the beginning of October, with a delay of approximately three weeks. ${ }^{92}$ Hochberg was then set out by and under the control of the Uzunköprü Security Inspectorate on the same day to the capital. The document found on him was also sent to Istanbul. ${ }^{93}$ The document was presented by the General Directorate of Security of the Internal Affairs Ministry on 24 October 1916, to the İstanbul General Police Directorate and then to Fifth Branch Directorate with the explanation that it might be objectionable ${ }^{94}$

Volume 12

Prior to Sami Hochberg's arrival in Istanbul, a preliminary preparation for his judicial proceedings was initiated and a criminal case was decided to be filed. In line with this decision, since the well-known statement of Hocberg received at the Sofia Military Police branch was needed, the Ministry of Interior had requested that a copy of the statement be provided and sent by applying to the Deputy Chief of State at the beginning of October. Thus, on 5 October 1916, the Head Commandship general intelligence headquarter office provided that statement through Sofia Military attaché service and presented it to the internal security. ${ }^{95}$ On 18 October, the documents were sent to the Ministry of Foreign Affairs General Printing Directorate for the translation. ${ }^{96}$ The requested translation was made immediately and returned with the original one the next day. ${ }^{97}$ The statement given by Sami Hochberg, who will be evaluated below in

${ }^{88}$ BOA, DH.EUM. 5. Şb., 32/33; p. 47; 18 Ağustos 1332/31 August 1916; BOA, HR.SYS, 2267/37; p. 2; 18 Ağustos 1332/31 August 1916; For the French text which received from the embassy, see. BOA, HR.SYS, 2267/37; 18 Ağustos 1332/31 August 1916.

${ }_{89}^{80 A}$ BO DH.EUM. 5. Sh., 32/33; p. 45; 28 Ağustos 1332/10 September 1916; HR.SYS, 2267/41.

${ }^{90}$ BOA, DH.EUM. 5. Şb., 32/33; p. 51; 25 Ağustos 1332/7 September 1916; BOA, HR.SYS. 2267/41; p. 1.

${ }^{91}$ BOA, HR.SYS, 2267/37; 14 Eylül 1332/27 September 1916.

92 BOA, HR.SYS.2267/41; p. 3-4.

93 A missive which was sent from Internal Affairs Ministry's General Directorate of Security to the $5^{\text {th }}$ Office Directorate: BOA, DH.EUM. 5. Şb., 32/33; p. 43; 4 Teşrinievvel 1332/17 October 1916

${ }^{94}$ BOA, DH.EUM. 5. Şb., 32/33; p. 23; 11 Teşrinievvel 1332/24 October 1916.

${ }^{95}$ BOA, DH.EUM. 5. Sh., 32/33; p. 39; 22 Eylül 1332/5 October 1916

${ }^{96}$ The text sent by Aziz, principal of the General Security; BOA, DH.EUM. 5. Şb., 32/33; p. 41; 5 Teşrinievvel 1332/18 October 1916

${ }^{97}$ From Foreign Affairs General Printing Directorate to General Directorate of Security: BOA, DH.EUM. 5. Şb., 32/33; p. 37; 6 Teşrinievvel 1332/19 October 1916. 
terms of his wrong-doings and good deeds, in Sofia on 14 September 1916, is the following in its simplified form:

'My name is Sami Hochberg. I was born in Istanbul. I am 47 years old. I have Jeune Turc Newspaper and its printing house. I am a Jewish citizen of the Ottoman Empire. I live permanently in Istanbul. I went to Bucharest a year ago and started serving the German embassy there. I worked there with my in-depth knowledge of the printing press and worked hard to create an opposition movement against the Romanian nationalists.

At the end of 1914, with the approval and financial support we received from Baron von Wangenheim $^{98}$, the German ambassador of the time in Istanbul; Dr. Weber ${ }^{99}$, the first translator of the embassy; Bussche ${ }^{100}$, German Ambassador in Bucharest; and Bronsart ${ }^{101}$, Germany's military attaché in Bucharest, we went to Bucharest with Besarya Efendi, the former Ottoman Minister of Public Works to publish a newspaper with the idea of cheering against the National Printing Press that supported the Entente States. In order to paint the eyes of the Romanians that I have already mentioned, we entered a party which was opposed to the Entente block by taking Romanian citizenship. However, we did not start publishing newspapers. Because in those days Monsieur Karpi set up the Moldovan newspaper to follow the same program. We gave up the idea of publishing the newspaper and devoted our power and work to the service of the German embassy. In this way, Master Besarya entered the world of politics, and I entered into journalism. We tried to serve the interests of the central European states.

In order to avoid attracting the attention of the Romanian government, we opened a trade office called 'Besarya and his Partners' in Bucharest with the consent of German ambassador Bussche. I was presenting my reports to Bussche and the military attaché Bronsart. Master Besarya presented his reports on me. I mostly gave more valuable information than those who were not satisfied with the Russians and spying for money, and I was entering into negotiations with the Jews of Russia. Later, we planned with military attaché von Bronsart to engage with them more intimately, and even to facilitate them to spy. According to this, we would deliver a wagon filled with medical supplies from Russia to Germany via Romania, to the Russian Jews. But that wagon was stopped and examined by Austrian officials in Brasso. That's why we had to wait a long time. Then it could cross over to Romania. This time, however, Romanian officials detained the wagon. At least I tried to save the price of medical equipment because I was acting as the deputy of the Berlin Chamber of Commerce. I'm not an ordinary merchant. I'm the acquaintance of the German military attaché, Bronsart. This situation can be asked and learned from him and the German General Warfare Staff Office.

\footnotetext{
${ }^{98}$ The German diplomat, whose full name was Hans Freiherr von Wangenheim, served as ambassador of Germany in the Ottoman Empire from 1912 to 25 October 1915. He died in İstanbul as a result of a heart attack and the Sultan of period attended his funeral. He was buried in the German Embassies summery in Tarabya. Wangenheim, who has infinite influence like insulting ministers, was among the people directing the Ottoman politic life. see. Munroe Smith, "War Books by American Diplomatists", Political Science Quarterly, Vol. 35, No. 1, March 1920, p.94-125; Selami Kılıç, "Birinci Dünya Savaşı'na Uzanan Süreçte Türk-Alman Yakınlaşması”, 1914'ten 2014'e 100'üncü Yılında Birinci Dünya Savaşı'nı Anlamak Uluslararası Sempozyumu, (20-21 November 2014-İstanbul), Harp Akademileri Printhouse, İstanbul 2015, p. 134; İlber Ortaylı, Osmanlı Imparatorluğu'nda Alman Nüfuzu, Timaş Pub., $11^{\text {th }}$ Edition, İstanbul 2010, p. 199.

${ }^{99}$ For Dr. Weber and his actions in İstanbul, see. Ahmet Asker, "Erken Cumhuriyet Döneminde Siyaset-TicaretMedya Üçgeninde Bir Gazeteci: Mehmed Zeki Bey", Atatürk Araştırma Merkezi Dergisi, Vol. XXXII, Iss. 94, Spring 2016, p. 54; Kılıç, “Birinci Dünya Savaşı’na Uzanan Süreçte Türk-Alman Yakınlaşması”, p. 144.

100 For Baron Von Dem Bussche see. Mark Osborne Humphries-John Maker, Germany's Western Front: Translations from the German Official History of the Great War: 1915, Wilfrid Laurier University Press, Canada 2010, p. 115-116, 143.

${ }^{101}$ For Günther Bronsart von Schellendorf see. Holger Afflerbach-David Stevenson, An Improbable War?: The Outbreak of World War I and European Political Culture Before 1914, Berghahn Books, New York 2007, p. 41, 80, 372.
} 
In short, the work to be done with the wagon was not successful. Therefore, the Austrians began to think that I was passing through transit with materials to Russia. They do not trust the German diplomats in Bucharest. In those days, I had to go to Switzerland to see my ailing wife. When I arrived in Brasso, the Austrians detained me again for 48 hours. Upon my request, the Austrian police appealed to the German embassy in Bucharest and released me after getting informed about my identity. I went to Switzerland. After three weeks there I went to Berlin for a week. On my return to Romania, I was again arrested in Brasso. They interrupted my contact with the German consul in Brasso and German Ambassador Bussche. I couldn't explain everything there. Because I was afraid to put Besarya and von Bronsart in jeopardy because there was no war declared between Romania and Austria. When the war was declared, we came to Budapest with the officers in Brasso, then to Nis and finally to here (Sofia).

Austro-Hungarians doubt me about my contact with the Mr. Besarya and Russians for the help of the Russian ambassador in order to bring the carriage to put into Russia. As I said, they were already distrustful of the German ambassador in Bucharest. The officer, who questioned me in Brasso, attributed the words I had never said. That's why I didn't sign the interrogation. Supposedly, I told Transylvania to be left to them for they join us. My bag stayed in Brasso.

$$
\begin{array}{r}
\text { I read and signed the statement above } \\
\text { Sami Hochberg } \\
14 \text { September } 1916 \text { - Sofia }
\end{array}
$$

Volume 12
Although his secret profession includes some unrealistic words as a requirement of espionage, as well as conditions, Hochberg's statements made in both Brashov and Sofia contain information that will enlighten many of the dark spots about what he did or did not. Starting with the unreal ones, Hochberg, for example, showed Istanbul as the place where he was born and lived. As it was mentioned at the beginning of the study, he was born in Dumbranevi in the territory of Besarabia, Russia, as of that day. The date of his arrival in the Ottoman country was determined as 1909. The fear that Allied Austria-Hungary and Bulgaria might perceive him as a Russian spy due to the war between Russia and those countries could be the reason why Hochberg did not use the word Russia. On the other hand, instead of making it clear in Brashov that he served for another ally, Germany, his expression that he was the paymaster of the German diplomats raises a distinct question mark in minds. In fact, the answer is also hidden in Hochberg's statement. For example, he expressed twice that the Austrians did not trust the German diplomats in Bucharest. Since there was no war between Austria and Romania, he said that he was unable to explain everything in Brashov because he feared that the information, he would convey could be dangerous on behalf of Master Beserya and Von Bronsart. The fact that he narrated this issue and other activities in Sofia to the Bulgarian officials, who were the other allies of Germany and the Ottoman states, indicates that he did not really trust the Austro-Hungarian Empire. He stated that the statament; 'in order for Romania to join us (the states of the Alliance), Transylvania should have left them' was never told by him and was ascribed to him by the officer who took his stament in Brashov, so he had not signed the interrogation documents. Moreover, as explained above, a document prepared in relation to the question was notified by the Austrian embassy in Istanbul on 31 August 1916 to the Ministry of Foreign Affairs, so that everyone, including the researcher, was aware of it. In

${ }^{102}$ BOA, DH.EUM. 5. Şb., 32/33; pp.25-29. 14 September 1916. See. Annex 2. 
short, he wanted to emphasize that the Austrians tried to create a legitimate ground for themselves in order to arrest him, and to do this they used the axis of ordering Transylvania to Romania.

For Hochberg, to take a look at Romania and Transylvania, determined as his target country or the main working area is important to be able to understand the activities that he or she is undertaking in that country. As it is known, Romania gained independence as a prize for its contribution to the Russian side in winning the 1877/78 Ottoman-Russian War. Following this development, the establishment of Great Romania was the main target of the Romanians. But it was not so easy to achieve. For this reason, it was necessary to take Bessarabia under the control of Transylvania under the Austro-Hungarian rule, which had an intensive Romanian population. In fact, the German military attaché in Romania (von Bronsart) mentioned in Hochberg statement reported in October 1914 'that the Romanians, who were completely Russian supporters, regarded Transylvania as a national goal, for now, they did not want Bessarabia'. With Romania's current power, it was impossible to add those territories to the borders of her country. It was necessary to get the support of one or more of the great states. World War I, which broke out between the Entente and Alliance Blocks, provided a unique opportunity for Romanians to achieve this goal. Although Romania declared its neutrality when the war began, it was on the agenda of both blocs as it was considered as a state that had the potential to significantly influence the fate of war with its strategic location and army. The combatant states wanted Romania to be included in the war on its side, and at least to remain neutral in their favor if it was not possible. In return, the Romanians had to ensure that the lands inhabited mostly by their cognates ${ }^{103}$ were abandoned to them. In the Austrian-dominated Transylvania, the Entente bloc was more prepared to provide Romania with what they wanted, as the Hungarian and the Germans lived alongside the Romanians. In fact, the Romanians had asked France and Britain, and especially Russia, to give them the land. ${ }^{104}$

The Romanian political circles and the public opinion were in complete division about whether or not to enter the war or not and if so, which bloc they would support. Prime Minister Bratianu, who shaped Romania's foreign policy at that time, was close to the Entente states since he was a French fan with liberal thought. He thought that by joining the war on their side, the Romanian lands could be united. However, he was extremely careful and cautious. As a matter of fact, he did not go after Austria, even though he was a member of the Triple Alliance when the war started. In the same way, he resisted the increasing pressures of the Entente States for two years. He built his diplomacy both before and during the war on seeing what the Entente States had fulfilled their commitments. It was the fact that he kept Romania out of the circle of fire until August 1916, despite many negotiations. In contrast, the working class in Bucharest was against the Entente States. Despite the government's inhibitions, in the summer of 1916, they began to voice their reactions more audibly. They did not hesitate to say that they

\footnotetext{
${ }^{103}$ The number and place of the Romanians living in different parts of Europe: about 2,500 in Transylvania, Banat, Crishana and Maramures; 250,000 in Bukovina within the borders of Austria-Hungary; 1 million people in Bessarabia under Russian domination and in Bulgaria, Macedonia and Serbia about 500.000. see. Nurten Çetin, “Romanya'nın Birinci Dünya Savaşı'na Girişi Ve Osmanlı Devleti'ne Etkileri”, Uluslararası Sosyal Araştırmalar Dergisi, Vol. 9, Iss. 42, February 2016, p. 537.

${ }^{104}$ See for details on what is promised to Romania and what is expected of her involvement in the war see. Musa Gümüş, "Birinci Dünya Harbinde Romanya'nın Savaş Diplomasisi”, Tarih ve Gelecek Dergisi, Vol. 3, Iss. 3, December 2017, pp. 65-70; Çetin, “Romanya'nın Birinci Dünya Savaşı'na Girişi Ve Osmanlı Devleti'ne Etkileri”, p. 536-537.
} 
would drop Bratianu's cabinet during the big demonstrations in front of the Russian embassy. Those who were supporters of the Russians continued to perform rallies and demonstrations. ${ }^{105}$

In short, from the end of 1914 to the end of August 1916, when he entered the First World War, the painting in Romania is as Sami Hochberg drew during his interrogation. He was involved in a job that bureaucracies and diplomats failed to do, and in order to integrate Romania into the Alliance bloc, he used his most powerful weapon, his writing ability, to create an opposition movement against the Russian in specific, and the Romanian nationalists who are generally pro-entente in general. This action also points to the time when he began to serve the German state as a spy. After the approval and financial support of the German diplomats in Istanbul and Bucharest, he stated that they went to Bucharest in October 1914 with the Mr. Besarya, who was the former Minister of Public Works of the Ottoman Empire with the idea of making publications against the national printing press which tended to support Entente Powers. His espionage is therefore not limited to carrying information and documents between Berlin-Bucharest and Istanbul. Making counter-propaganda, one of the important elements of intelligence, was part of the secret mission he was charged with.

The name that Sami Hochberg had with him for the actions he had planned to do in Romania was Master Besarya, who worked for the Germans as a spy like him. It was mentioned above that Mr. Besarya whose full name was 'Nicolae Constantin Batzaria' and who was also known as 'Ali Baba' in the Ottoman World, wrote a text in Le Jeune Turc during the Balkan Wars and took part in the Mahmoud Shevket Pasha's cabinet as Public Works Minister after 1913. He was born in 1874 in Macedonia as the child of a Romanian family. Following the Balkan Wars, he attended the London Conference (1913). In addition, he was sent to the region by the Ottoman government in secret missions in spite of the developments in the Balkans. After he stopped serving the Ottoman Government, he spent the rest of his life at Bucharest and died in 1952. He has an intellectual personality besides state man. ${ }^{106}$ Hochberg, as he had expressed during the interrogation, went to Bucharest to publish a newspaper with the idea of opposing the inclusion of national printing in Romania. However, after the start of the publication of 'The Moldovia' newspaper serving the same purpose, he gave up the idea and stated that he changed into journalism in another medium and that Master Besarya entered the political world and tried to serve the interests of the Central European states.

As they continued their activities, Hochberg had gone to Switzerland to see his wife, who in his own words was unwell at the time. Litmann, who quoted from Yigal Sarna, also stated that he had sent his wife and children to Switzerland because of illness and better standards of living. After this visit, Hochberg was arrested by Austrian-Hungarian officials at the border control on his way back to Romania. Litmann stated that Hochberg, who had been invalidated in 1916 due to the occupation of Romania by Transylvania (Erdel), was sent back to Istanbul and was accepted to the Ottoman territory as an American spy. ${ }^{107}$ However, the story of Hochberg's arrival in Istanbul, as witnessed by the documents and himself, is as mentioned above and there is a compelling acceptance. Speaking of which, it should be noted that

\footnotetext{
105 Çetin, “Romanya'nın Birinci Dünya Savaşı'na Girişi Ve Osmanlı Devleti’ne Etkileri”, p. 538-539; Gümüş, “Birinci Dünya Harbinde Romanya'nın Savaş Diplomasisi”, p. 70.

${ }^{106} \mathrm{He}$ had a book named "Din Lumea İslamilui, Turcia Junilor Turci" (From the World of Islam, The Turkey of the Young Turks) printed in 1922 Bucharest and prepared by Alcalay Calafetea (see. Mutlu, Osmanll'da Bir Ermeni Hariciye Nazırı Gabriel Noradunkyan Efendi, p.15). To bring it to Turkish, Assoc. Prof. Nevzat Artuç carried out within the scope of a project with this work an independent private political biography covering the life and ideas in Romania and Turkey in the name of "Besarya Efendi ve İttihad ve Terakki Dönemi Üzerine Hatıraları" (Master Besarya and his memoirs on Union and Progress period).

${ }^{107}$ Littman, "Saved from History's Black Hole".
} 
Hochberg and Beserary Effendi have failed to achieve the result they had intended from the activities they were trying to carry out. This negativity has nothing to do with the capture of Sami. Because after a few months of his capture, Romania won victories on the fronts on 17 August 1916, and as a result of a secret treaty with Britain and France promising places such as Transylvania, Romania would be included in the war on the territory of the Allied Powers, and on August 28 they will declare war on the Austria-Hungarian Empire ${ }^{108}$. Thus, the means by which the Germans had been using for almost 2 years, including the Hochberg channel, to get it into battle on the Central Powers. It was interesting for this study to note that three days after Romania declared war on them (31 August 1916), the Austrian-Hungarian Empire knocked on the door of the Ottoman foreign ministry for the delivery of Sami Hochberg.

\section{Hochberg the Reliable}

From what has been reported so far, Sami Hochberg seems to have left a story in every city. Those taking part in the last two places of the stories list took place in the first and last capitals of the Ottomans. He was brought to Istanbul in the days when the statement of remarks in Sofia, which was mentioned a few times above, reached the Ministry of Internal Affairs. Although it was reflected in the previous correspondence, no lawsuit was filed. Even though he had explicitly stated in his statement that he was working for the benefit of the Germans, an ally of the Ottomans, there was no change in the negative attitude of Mr. Talat, Minister of Internal Affairs, regarding Hochberg. As a matter of fact, he has a statement about him saying, 'even though his espionage has not accrued, he has been recognized as a Zionist person from time to time and his residence in Istanbul will suffer and therefore, he has to be exiled.' On 30 October 1916, in order to transform this statement into action, that is to take Hochberg from Istanbul, he wrote the situation to the Supreme Military Office so that the military decision necessary due to the warfare could be issued. The decision he desired was issued as 'the deportation of Sami Hochberg to Bursa is eligible' and signed by Enver (Pasha) on 12 November 1916. ${ }^{109}$ Three days later, Mr. Talat told police chief Mr. Ahmed, that the exile of Sami was designated as Bursa and that he should be transferred there immediately. ${ }^{110}$ The case was forwarded to İstanbul Central Commandership, which would carry out the exile the next day. For some reason, the Commandership did not act as hastily as the Ministry of Interior. In an article written by Central Commander Cevad about two weeks later (30 November) in response to the Ministry of Interior, a document was requested on the issue that required the expulsion of Sami Hochberg. This document would be returned to the Ministry once the information it contained was recorded in the book kept for the deported. On 7 December 1916, Talat wrote a summary of the developments in the Hochberg axis. ${ }^{111}$ In his words, Hochberg was the director of the Le Jeune Turc newspaper repealed by the military. According to the information received from the Headquarters General Intelligence Branch, the correspondent was spying on the Germans in Bucharest. However, it could not yet be possible to confirm this point. Even so, Hochberg has been known as a Zionist for a long time. This is why it was not appropriate for him to stay in Istanbul. There was the decision of the Supreme Commander that Hocberg should be exiled to Bursa, and this decision was also communicated to the Police

\footnotetext{
${ }^{108}$ Enver Ziya Karal, Büyük Osmanlı Tarihi, Vol. V, TTK, $7^{\text {th }}$ Edition, Ankara 2007, p. 481-482; Gümüş, "Birinci Dünya Harbinde Romanya'nın Savaş Diplomasisi”, p. 70-72; Kemal Karpat, "Erdel”, TDV. İA, Vol. XI, İstanbul 1995, p. 282.

${ }^{109}$ BOA, DH.EUM. 5. Şb., 32/33; p. 19; 30 Teşrinievvel 1332/12 November 1916.

${ }^{110}$ BOA, DH.EUM. 5. Şb., 32/33; p.21; 2 Teşrinisani 1332/15 November 1916.

${ }^{111}$ From İstanbul Central Commandership, Customary Administration Office to Internal Affairs Ministry: BOA, DH.EUM. 5. Şb., 32/33; p.15; 17 Teşrinisani 1332/30 November 1916.
} 
Directorate General. If this information is not sufficient, further details are needed, it will be appropriate to apply to the General Headquarter. ${ }^{112}$

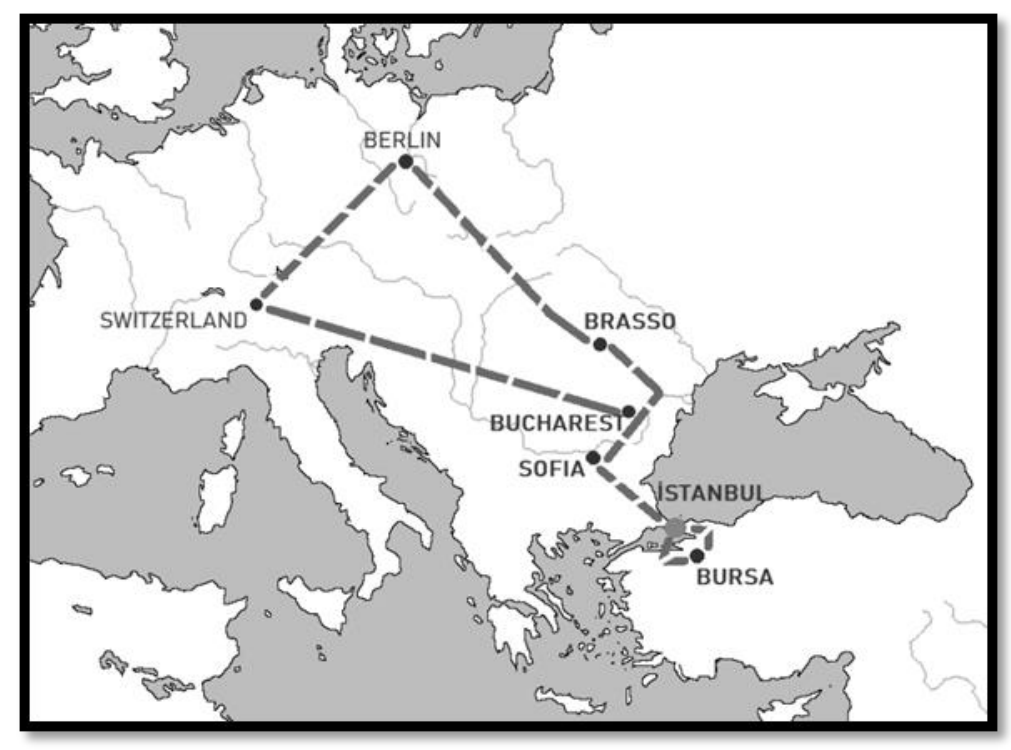

Figure 4: Sami Hochberg's Life Map III - (1915-1917)

After the correspondence traffic between the Ministry of Internal Affairs and the Central Command and a long wait, Sami Hochberg was finally exiled to Bursa on 18 December 1916. Thus, when the pages of the history of Istanbul concerning Hochberg's story were about to close with the pen force of Talat Bey, an unexpected development occurred. Talat Bey, who had just made a great effort to exile Hochberg fast from the last capital to the first, now was encountered trying to stop the exile with similar speed and effort. As a matter of fact, the order dated 25 December 1916, which was signed by him, wanted the police chief Mr. Ahmed to release Hochberg and to report the situation if it was too late. ${ }^{113}$ The answer, which came three days later from the Police Directorate, informed that Hochberg was exiled to Bursa on 18 December in accordance with the order of the Internal Affairs Ministry on 15 November 1916. ${ }^{114}$ Therefore, the addressee of Talat Bey was now the province of Hudavendigar which Bursa was affiliated to. As a matter of fact, in a cryptic manuscript sent with the signature of Minister Talat on the last day of 1916, it was asked from the Hüdavendigar Governorate to let Hochberg return to İstanbul. ${ }^{115}$

So what was the development that led the Zionist Hochberg to be recalled in the same way from the exile place where he was sent hastily? Even though the documents are silent in this respect, it is not difficult to predict what lies in the background of change in the light of recent developments. After all, the contents of the correspondence made between the Ottoman military and civilian authorities after Hochberg was recalled to Istanbul are of a kind that will not leave any secrets behind about Hochberg's trip to Bursa-Istanbul. The development that paved the way for the aforementioned correspondence traffic is an article from the German

${ }^{112}$ A missive from Talat, Internal Affairs Minister to the Cevad, Central Commander: BOA, DH.EUM. 5. Şb., 32/33; p.17; 24 Teşrinisani 1332/7 December 1916.

${ }_{113}^{13}$ BOA, DH.EUM. 5. Şb., 32/33; p.9; 12 Kânunuevvel 1332/25 December 1916.

${ }^{114}$ From İstanbul General Police Directorate politic section to Internal Affairs: BOA, DH.EUM. 5. Şb., 32/33; p.13; 15 Kânunuevvel 1332/28 December 1916

${ }^{115}$ BOA, DH.ŞFR, 71/115; 17 Kanun-1 Evvel 1332/30 December 1916. 
Embassy in Istanbul at the beginning of 1917 reaching the headquarters of the General Directorate of Public Intelligence Branch of Supreme Military Command. The Germans had a request from the Ottoman decision-makers related to Hochberg; they planned to send him to Berlin in order to transfer to Russia via Sweden as a spy. Now they asked whether the Intelligence Branch would allow him to be sent to Berlin. The German question was addressed to the Ministry of Internal Affairs, General Directorate of Security Affairs on 8 January 1917. It was requested that the situation be reported to the Intelligence Department and the Police Directorate, If Hochberg was approved to be sent by the Minister Talat Bey. ${ }^{116}$ It should be noted that, after these last correspondence and the information they contain, the Germans were the ones who guided Hochberg's last journey between the Ottoman Capitals, although it would no longer mean anything but to declare the known. It is also understood from the correspondence that after he was brought to Istanbul, he was held under the supervision of the police under arrest or detention.

The Minister of Internal Affairs, Talat Bey, who strongly opposed Hochberg's submission to Istanbul when he was arrested in Brashov, but stepped back on the request of Allied Austria, who quickly made Hochberg exiled to Bursa when he arrived in Istanbul but called him back to the capital upon the request of the other allied Germans, unhesitatingly accepted the Germans' demand of sending him to Berlin, as if he did not want to fall into a new error. In fact, Head of General Security Aziz Bey said in his reply dated 11 January 1917 addressed to Mr. Seyfi, General Headquarter of Intelligence 2nd office manager (Major of General Warfare Staff) that it was approved by the Ministry of Internal Affairs that Sami went to Berlin and that necessary notification had been made to the officers like Police Chief Ahmed Bey. In addition, in an article written by Mr. Vasif, the Director of the Fifth Division, to inform the Directorate of Navigation, it was stated that Sami Hochberg had been authorized by the Ministry of Interior to take the train to Berlin. ${ }^{117}$

Following the provision of the necessary permits and means, for Hochberg, a new city, and therefore the door to a new story is about to be opened. At this point, as if they wanted to deny the researcher, the documents seem to have chosen to remain completely silent on whether or not Hochberg's story ends in Istanbul, in other words, whether or not he was on that trip and even in all matters related to it. Fortunately, the literature comes to the help, and informs us that for Hochberg instead of a new journey the last of them had happened: he died in a restaurant where he was eating in Istanbul, as a result of food poisoning. There is no precise information on where death caught him. What is certain is that the incident took place on 23 February 1917 when he met Richard Lichteim, the official representative of the World Zionist Organization in Istanbul. ${ }^{118}$ Ygal Sarna believes that poisoning was a good way to ensure that the unwanted people were liquidated in the empire at that time and that he fell into the trap and into the wrong hands. He also notes that there was no investigation into his death, or trace of where he was buried. ${ }^{119}$ No statement regarding this issue has been found in the literature and documents. If it is believed that death took place outside of the apparent event of food poisoning, many comments could be made. The first thing that comes to mind is probably that he would be taken away from the Ottoman police by the Germans and killed as he was deciphered. The Zionist Organization, which does not have much respect for him, may also have been involved in this work. Indeed, Hochberg last met with R. Lichteim. However, they are doomed to remain just a comment since they are not supported by other sources.

${ }^{116}$ BOA, DH.EUM. 5. Şb., 32/33; p. 3; 26 Kânunuevvel 1332/8 January 1917.

${ }^{117}$ BOA, DH.EUM. 5.Şb., 32/33; p. 1; 29 Kânunuevvel 1332/11 January 1917.

${ }^{118} \mathrm{https} / / /$ catalogue.bnf.fr/ark:/12148/cb165628254

119 Littman, "Saved From History's Black Hole". 


\section{Conclusion}

If there is a ranking among people living the most active and heated days of their time, the name Sami Hochberg can be found in the list. The two sides of the coin would be an insufficient description for that name. He is the representative of a nomadic life from the years of youth. He is a journalist and writer who serves Zionism. Printing and publishing is an extension of the profession of journalism, and for the profession of espionage, it was almost as if it was a lightning rod. The congresses he attended or his meetings made it possible to introduce him as a representative and as an important diplomat of Zionism. For Hochberg, the medallion cannot be made up of two sides. His life, which began as a Russian Jew in a remote town in Bessarabia, ended in Istanbul as an Ottoman citizen. That experience contains many mysteries that are inconvenient to use in an academic study. His transnational and crosscontinental travels, his intimacy and busy shift with the Ottoman and German bureaucrats and diplomats deepen mysterious sphere of his life more. The reason why the researcher's preferred item sometimes tends to go beyond academic boundaries is that it is a work or coercion of that mystery. The difficulty of fitting the hero offering such a lively and colorful life into classical sentences has created a relatively free pen usage site.

The name Sami Hochberg, in the minds of the rulers of the Ottoman Empire (1909-1914), created a Jewish portrait trying to practice the profession of journalism and printing in his own case, or there has been an acceptance in that way. The policies of rapprochement and convergence that the Unionists pursued against the Arabs and Jews as a challenge of the financial conditions of the country, of course, had an undeniable influence in shaping the portrait. However, with the hearing of the sounds of guns that warned of the beginning of the war, there was no trace of that portrait nor the politics. Sami Bey lost his newspaper and printing press in the war initiated by the Ottoman government against Zionism and its representatives in Istanbul. Like his other friends, he is now an extremely harmful person who has served life in Zionism, in the eyes of the Ottoman bureaucrats. This is the reason for the follow-up he underwent in Turkey and abroad. After his arrest in the border control, his statement in Sofia brought a new identity and adjective for him in his Ottoman documents: Sami the spy. Those who directed the activities in this capacity were German diplomats in the Ottoman and Romanian countries. Not only the Ottomans but also those of the military class of the Germans, are not aware of this situation. This is confirmed by the fact that the German Admiralty Rangers' disclosed Hochberg's activities and meetings in Bucharest to Istanbul in accordance with the request of the Ottoman Government. The answer to the question of why Germany, not Russia, was quoted in the text.

Even if the activities such as journalism, printing, diplomatic representation or espionage have failed in the general picture, the events experienced by Hochberg or the events that took place in his axis make it possible to see and understand not only the period he lived in but also the historical background that paved the way for today's global competition and conflicts. In this context, the role of the Great Powers in the shaping of the modern world, the paths and procedures of the Zionists in the policy of settling in Palestine, the Arab-Jewish conflict related to this, the attitude of the other states, especially the Ottoman Empire, and the roles they played in this conflict could be seen in Sami Hochberg's short, but lively and active life. Moreover, in Hochberg's Istanbul-based life, there are historical elements that would allow us to gain perspective on the issues such as how the bureaucratic structure in the Empire works, the relations of the Unionists with their European enemies and their own connections, besides, their policies towards Arabs and Jews, and more importantly, what was the cause of excessive volatility and breakage in politics. 


\section{References}

\section{Archive Sources*}

Turkey Republic - Presidency State Archives, Ottoman Archive (BOA)

Bâb-ı Âli Evrak Odası (BEO): 4163/3112224.

Dâhiliye Emniyet-i Umûmiye Müdüriyeti 5. Şube (DH.EUM.5.Şb): 22/28; 32/33; 81/12.

Dâhiliye Muhaberat-ı Umumîye İdaresi (DH. MUi): 143/23

Dâhiliye Şifre (DH. ŞFR): 71/115.

Hariciye Siyasî (HR. SYS): 2267/19; 2267/23; 2267/37; 2267/41.

İrâde Meclis-i Mahsus (İ. MMS): 163/15.

Meclis-i Vükelâ Mazbataları (MV): 231/45.

Şura-yı Devlet (ŞD): 3115/1.

\section{Literature}

AFFLERBACH, Holger, STEVENSON, David. An Improbable War?: The Outbreak of World War I and European Political Culture Before 1914, Berghahn Books, New York 2007.

ASKER, Ahmet, "Erken Cumhuriyet Döneminde Siyaset-Ticaret-Medya Üçgeninde Bir Gazeteci: Mehmed Zeki Bey”, Atatürk Araştırma Merkezi Dergisi, Vol. XXXII, Issue. 94, Güz 2016, pp. 49-89.

AYTÜRK, İlker, "Celâl Nuri”, Encyclopedia of Jews in the Islamic World, (Ed. Norman A. Stillman), Vol. I, Brill, Leiden 2018.

BERKES, Niyazi, Türkiye'de Çağdaşlaşma, Ed. Ahmet Kuyaş, YKY, İstanbul 2008.

CANATAR, Mehmet-BAŞ, Yaşar, "Şura-yı Devlet Teşkilatı ve Tarihi Gelişimi”, OTAM, Issue. 9, Ankara 1998, pp. 107-139.

ÇAM, Mehmet Mert, "Birinci Dünya Savaşı'nda Filistin'deki NİLİ Ajanları'nın Faaliyetleri”, Yeni Türkiye, Issue: 86, Ankara 2016, pp. 286-294.

ÇAY, Mustafa Murat, Cevat Rifat Atilhan-Askerî, Siyasî ve Fikrî Yönleriyle, Selçuk University Graduate School of Social Sciences (Unedited) PhD. Thesis, Konya 2013.

ÇELIK, Hümeyra, Başlangıcından II. Meşrutiyete Osmanlı İmparatorluğu’nda Basın, Süleyman Demirel University Graduate School (Unedited) Ma Thesis, Isparta 2012.

ÇETIN, Nurten, “Romanya'nın Birinci Dünya Savaşı'na Girişi Ve Osmanlı Devleti'ne Etkileri”, Uluslararası Sosyal Araştırmalar Dergisi, Vol. 9, Issue. 42, February 2016, pp. 536-551.

ÇOBAN, Melih, "Ottoman Jews in Salonica: A Community At The Heart Of Ottoman Enlightment", Turkish Review of Balkan Studies, Vol. 11, 2007, pp. 69-84.

EBÜZZIYA, Ziyad, “Ebüzziya Mehmed Tevfik”, TDV. IA , c. X, İstanbul 1994, pp. 374-378.

ENGIN, Vahdettin, Pazarlık, Yeditepe Pub., 22 ${ }^{\text {th }}$ Edition İstanbul 2018.

\footnotetext{
* Documents full identities given in the text.
} 
ERÖZ, Mehmet, "Parvus'un Türkiye Hakkındaki Yazıları", İstanbul Üniversitesi Ikktisat Fakültesi Mecmuasl, Vol. 43, İstanbul 1987, pp. 347-356.

GENCER, Mustafa, Jöntürk Modernizmi ve “Alman Ruhu”, İletişim Pub., İstanbul 2010.

GÜLERYÜZ, Avigdor Naim, “Alliance Israelite Okulları,” Dünden Bugüne İstanbul Ansiklopedisi, Vol. 1, İstanbul 1993.

Edition, İstanbul 2015. , Türk Yahudi Basını Tarihi - Süreli Yayınlar, Gözlem Pub., $1^{\text {th }}$

GÜMÜŞ, Musa, "Birinci Dünya Harbinde Romanya'nın Savaş Diplomasisi”, Tarih ve Gelecek Dergisi, Vol. 3, Issue. 3, December 2017, pp. 62-76.

HALIGUA, Eli, "Yarım Asırdan Fazla Bir Süre Önce, Türkiye Yahudi Basınında İki Gazete", http://www.avlaremoz.com/2016/07/05/yahudi-basininda-iki-gazete/, Access Date: 11.12.2018.

HUMPHRIES, Mark Osborne-MAKER, John. Germany's Western Front: Translations from the German Official History of the Great War: 1915, Wilfrid Laurier University Press, Canada 2010.

KARAL, Enver Ziya, Büyük Osmanlı Tarihi, Vol. V, TTK, $7^{\text {th }}$ Edition, Ankara 2007.

KARPAT, Kemal, "Erdel”, TDV. İA, Vol. XI, İstanbul 1995, pp. 280-283.

KILIÇ, Selami, "Birinci Dünya Savaşı'na Uzanan Süreçte Türk-Alman Yakınlaşması", 1914'ten 2014'e 100'üncü Yılında Birinci Dünya Savaşı'nı Anlamak Uluslararası Seтроzуити, (20-21 Kasım 2014-İstanbul), Harp Akademileri Basımevi, İstanbul 2015, pp. 91-156.

KURAN, Neslihan, 19. Yüzyılda İstanbul'da Açılan Alliance Israelit Universelle Okullarl, Selçuk University Graduate School of Social Sciences (Unedited) Ma. Thesis, Konya 2009.

LEWENTAL, D. Gershon, "Benaroya, Albert", Encyclopedia of Jews in the Islamic World, (Ed. Norman A. Stillman), Vol. I, Brill, Leiden 2018.

, "Ha-Mevasser", Encyclopedia of Jews in the Islamic World, (Ed. Norman A. Stillman), Vol. II, Brill, Leiden 2018.

. "Le Jeune Turc", Encyclopedia of Jews in the Islamic World, (Ed. Norman A. Stillman), Vol. III, Brill, Leiden 2018.

LITTMAN, Shany, "Saved From History's Black Hole", Haaretz, 12.11.2010, Access Date: 19.12.2018., https://www.haaretz.com/1.5138700.

MANDEL, J. Neville, "Attempts at an Arab-Zionist Entente 1913-1914", Middle Eastern Studies, Vol. 1, Issue: 3, 1965, pp. 238-267.

MUTLU, Cengiz, Osmanlı'da Bir Ermeni Hariciye Nazırl Gabriel Noradunkyan Efendi, Gündoğan Pub., İstanbul 2015.

ÖKE, Mim Kemal, Siyonizm ve Filistin Sorunu (1880-1923), Timaş Pub., $7^{\text {th }}$ Edition, İstanbul 2018.

SHAW, J. Stanford, Osmanlı Imparatorluğu'nda ve Türkiye Cumhuriyeti'nde Yahudiler, Trans. Meriç Sobutay, Kapı Pub., İstanbul 2008. 
SMITH, Munroe, "War Books by American Diplomatists", Political Science Quarterly, Vol. 35, No. 1, March 1920, pp. 94-125.

SÖYLEMEZ, Mehmet Mahfuz, "Kudüs ve Osmanlı Arşiv Vesikaları Işı̆̆ında Yahudilerin Bölgeye Yerleşmeleri Üzerine Notlar", Siirt Üniversitesi Illahiyat Fakültesi Dergisi, Vol. 1, Issue. 2, 2014, pp. 33-56.

TAUBER, Eliezer, "A Report on Arab-Jewish Negotiations During the Young Turk Regime", Turcica, Issue: 31,1999 , pp. 471-488.

YÜKSEL, Ahmet - GÜVEN, Okan, "Building an Image in Each Language with Jöntürk Newspaper Manager Mr. Sami: Ottoman Publishing Company", Science Beyond Boundaries II - Thematic Collection of Papers of International Significance, Universitet i Priştini Filozofski Fakultet, Kosovska Mitrovica 2019, pp. 3-26. 


\section{ANNEXES}

Annex-1: French Memorandum received from the Austrian-Hungarian Embassy (BOA, HR.SYS., 2267/37, p. 2; 18 Ağustos 1332/31 August 1916.)

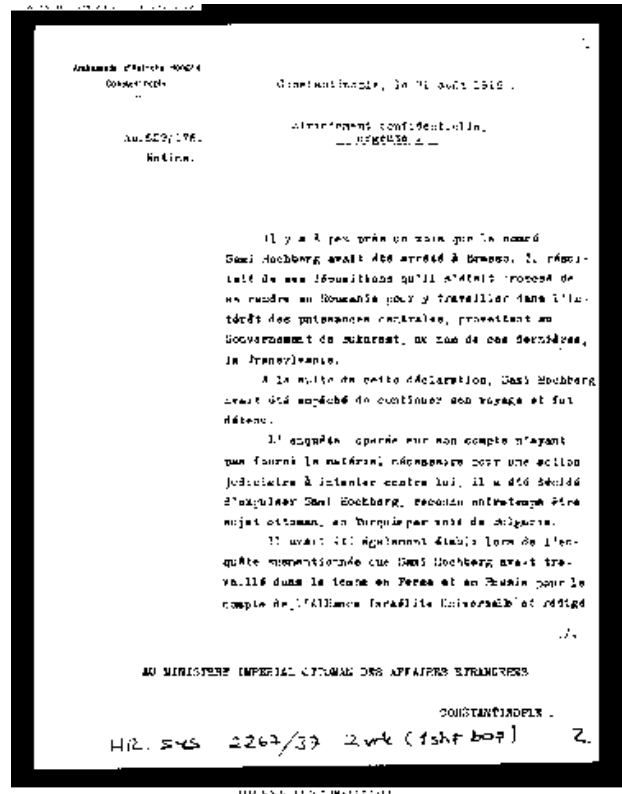

Annex-2: Sami Hochberg's Interrogation taken in Sofia

Volume 12 (BOA, DH.EUM. 5. Şb. 32/33, p. 25, 2914 September 1916.)

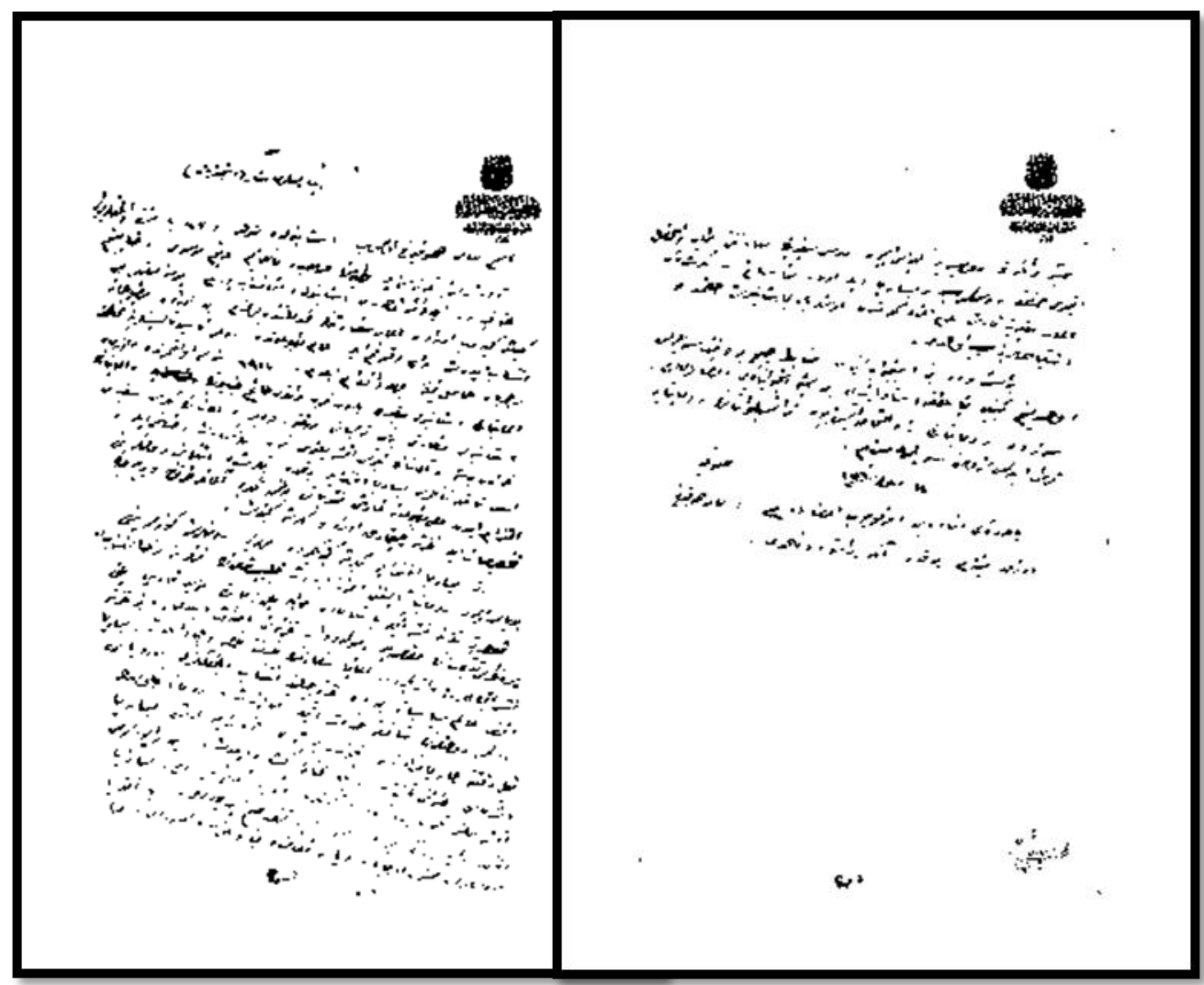


Annex-3: The Documents which showedthe prosecutions of the Zionists in İstanbul (BOA, DH.EUM. 5. ŞB. 81/12, p. 9, 11; 15 Nisan 1331/28 April 1915.)

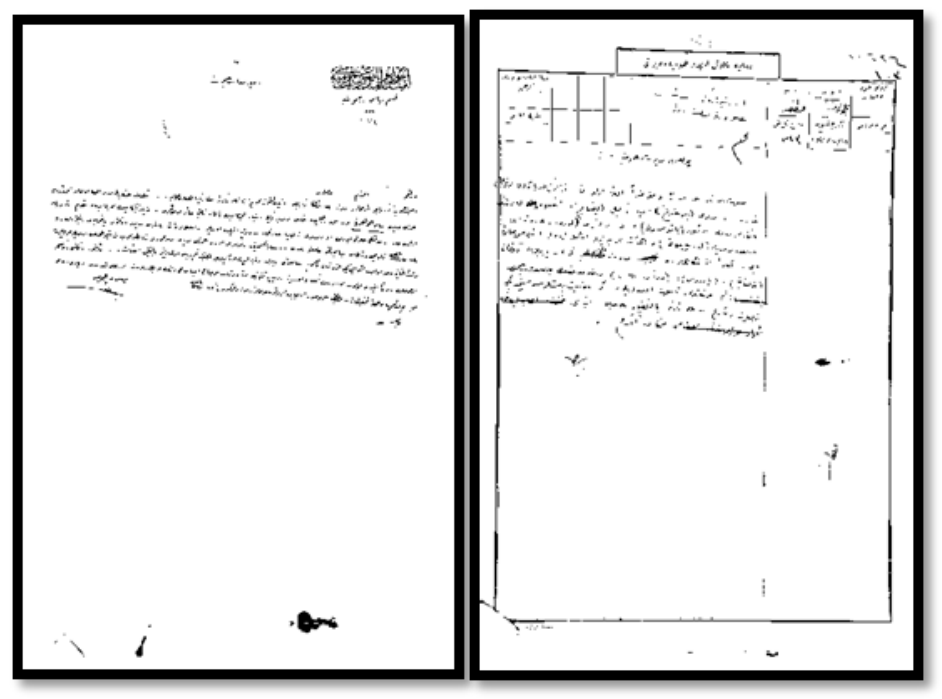

Annex-4: A Document Reporting that Sami Hochberg was from the Ottoman Citizen STUDIES (BOA, DH.EUM. 5. ŞB. 32/33, p.51; 28 Ağustos 1332/10 September 1916.)

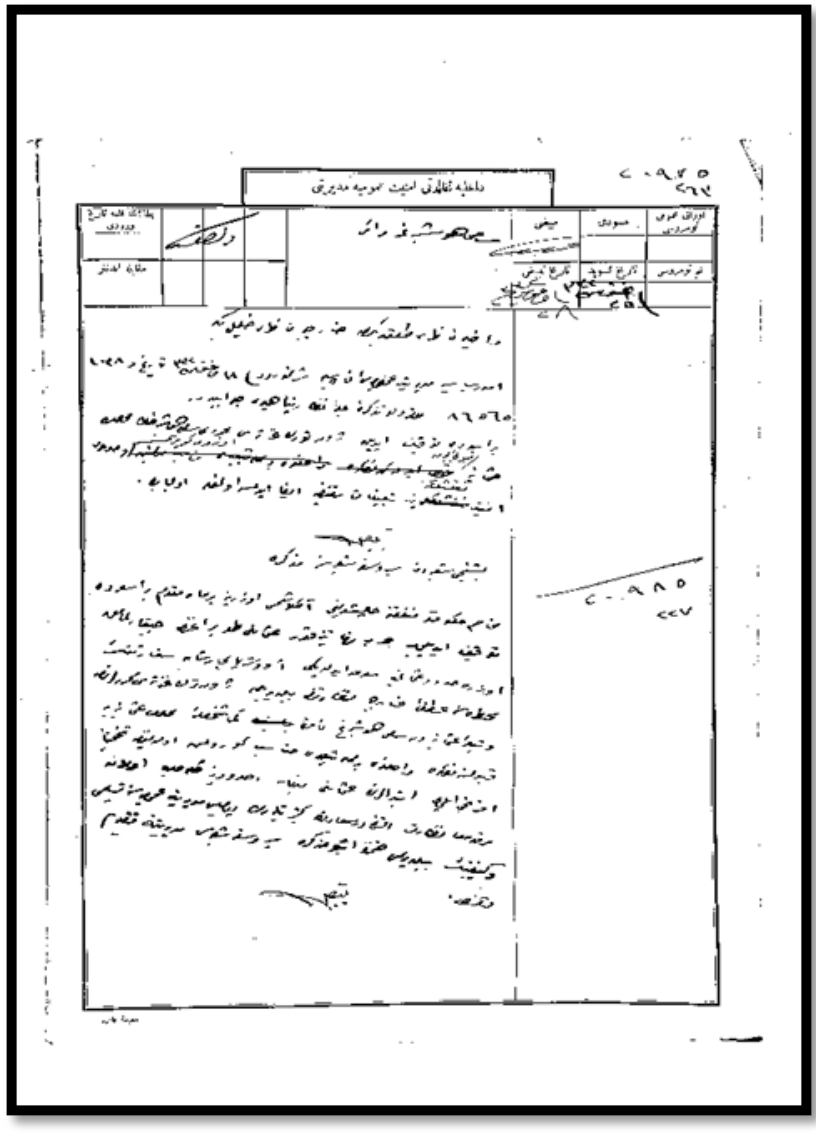

Volume 12

Issue 4

August

2020 
Annex-5: The French Telegramme about Sami Hochberg was a Serbian Spy according to the statements of Austro-Hungarian Government which sent by the Ambassador of Vienna, Hussein Hilmi Pasha to Foreign Affairs Minister Mr. Halil.

(BOA, HR.SYS. 2267/19, p.1; 9 June 1916.)

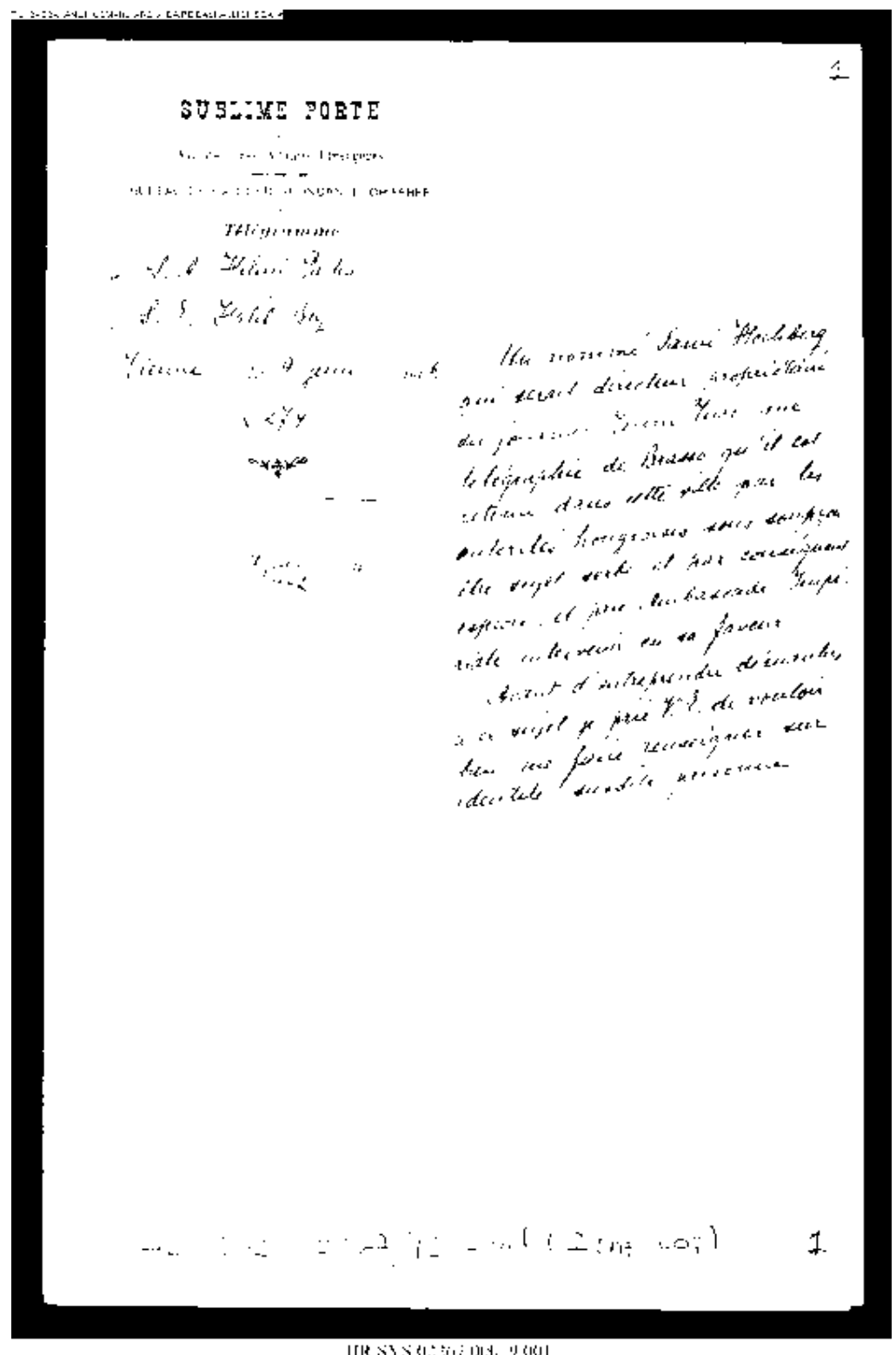

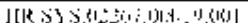

